

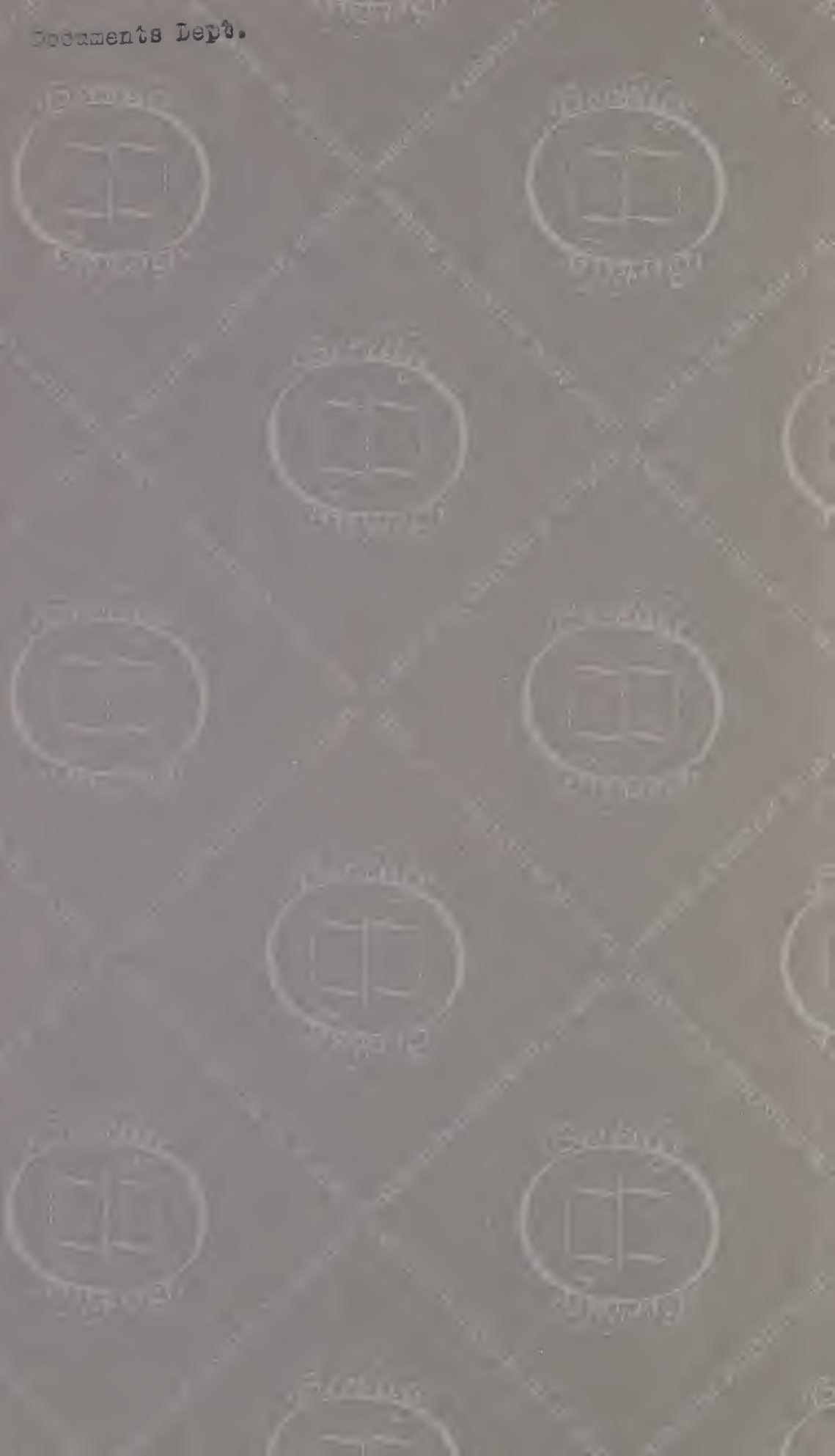




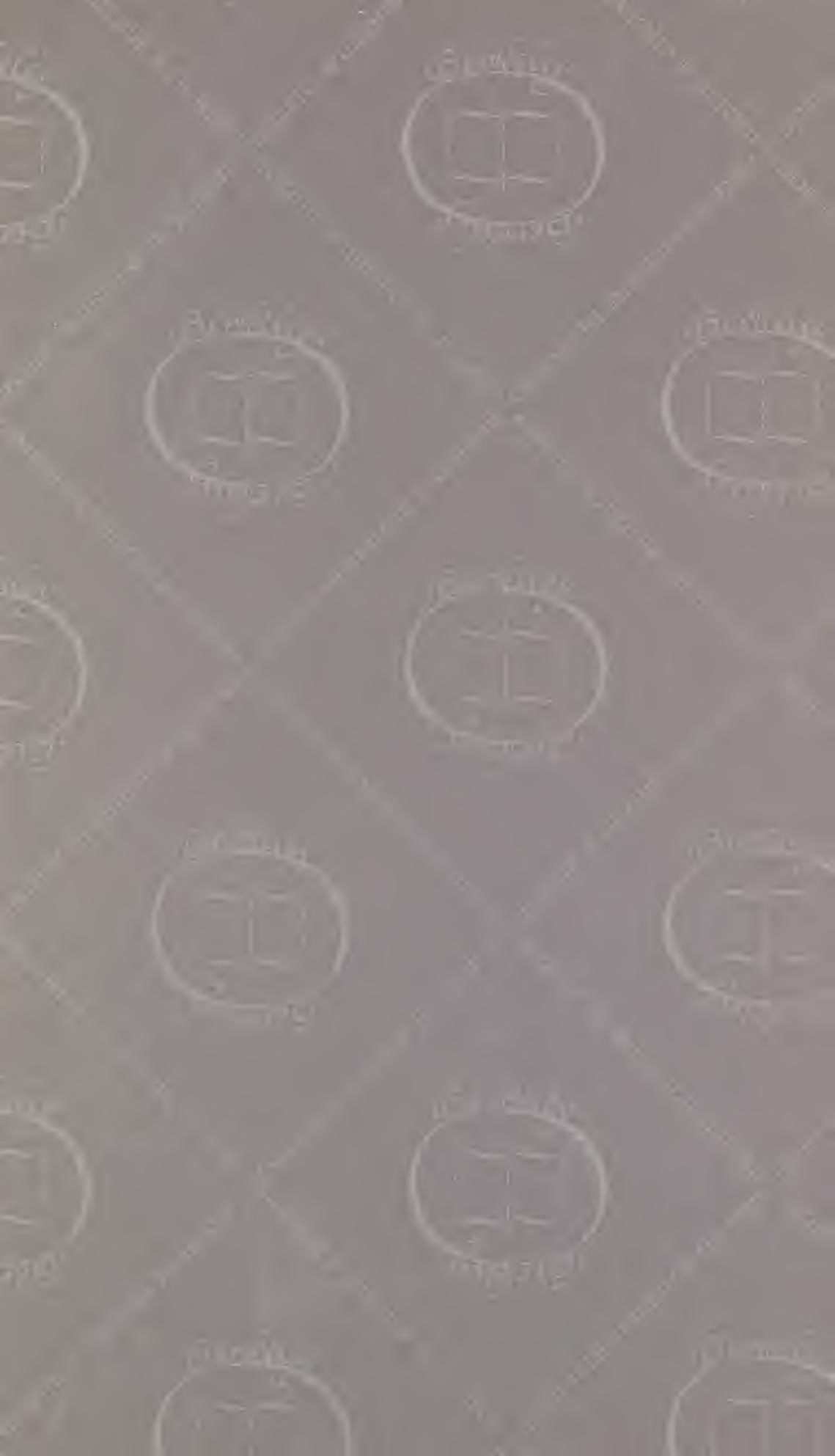





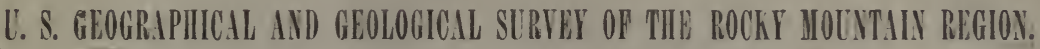

J. W. POWELL, IN CHARGE.

\section{PRELIMINARY REPORT}

ON THE

\section{PALEONTOLOGY OF THE BLACK HILLS,}

BY

R. P. WHITFIELD,

CONTAINING DESCRIPTIONS OF NEW SPECIES OF FOSSILS FROM THE POTSDAM, JURASSIC, AND CRETACEOUS FORMATIONS

OF THE BLACK HILLS OF DAKOTA.

WA S H I N G T O N :

GOVERNMENT PRINTING OFFICE.

July, 1877. 



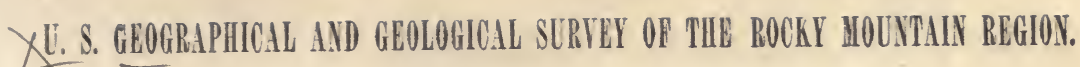

J. W. POWELL, IN CHARGE.

\section{PRELIMINARY REPORT}

ON THE

PALEONTOLOGY OF THE BLACK HILLS,

R. P. WHITHIELD,

CONTAINING DESCRIPTIONS OF NEW SPECIES OF FOSSILS FROM THE POTSDAM, JURASSIC, AND CRETACEOUS FORMATIONS

OF THE BLACK HILLS OF DAKOTA.

WA S H I N G TON:

GOVERNMENT PRINTING OFFICE.

July, 1877. 


\section{Docament; Dant.}

\section{NOTE.}

The new species of fossils described in this preliminary report, by Professor R. P. Whitfield, from the Potsdam, Jurassic, and Cretaceous formations, are such forms as are new to science in the collections made by W. P. Jenney and $\mathrm{H}$. Newton during the exploration of the Black Hils of Dakota in the summer of 1875 .

These forms, with many others from the same formations, are embodied in the final report on the paleontology of this region, which, with sixteen lithographic plates, will accompany the publication of the final results of the exploration in the Black Hills.

July, 1877. 


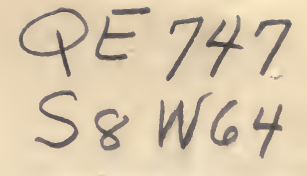

DOCUMENIS

DEPT.

\section{PRELIMINARY REMARKS.}

The species described in the following pages were collected in and around the Black Hills during the expedition, and represent the different formations recognized, except the Carboniferous, from which the fossils obtained were few and of little interest.

The horizon of the Potsdam formation of the Black Hills appears to be, so far as the fossils will serve to determine, about the same as that of Wisconsin and the neighboring States; and of some of the layers the lithological features are so nearly the same that it would be difficult to distinguish between specimens from the two localities. The purplishgreen quartzitic rock from the head of Red Cañon Creek, containing Lingulepis pinniformis Owen sp. aud several other Brachiopodous shells, appears to hold nearly the same relation to the rest of the group as does that at the Falls of the St. Croix, from which the species was originally described, namely, near the base; the Red Cañon Creek beds resting immediately on the slates of older date (probably Huronian) while the Trilobitic beds and the soft friable layers occur at a horizon of about 100 feet below the Carboniferous. The entire fauna of the Black Hills beds closely resembles that from Wisconsin; although the species are nearly all distinct, the generic facies is the same throughout. Among the fossils from the higher parts of the formation there are quantities of Plant remains belonging to the genus Palcophycus which, I am informed, cover the surface of the rocks over large areas where exposed, being densely matted together. These beds also hold a position similar to the Plant beds of other localities.

The Jurassic formations seem also to be well represented in this region, and many of the beds are highly fossiliferous. The species are not numerous, but the indiriduals are extremely abundant, many of the slaty calcareous layers being so largely composed of organic remains, mostly Lamellibrauchiates, as to be quite friable and easily broken in the hand, and some of the sandy layers have their surfaces densely cor. ered with the separated shells of one or two species. The absence of Gasteropoda is a noticeable feature at all localities from which specimens have been brought, no example of this class of molluses being present in the entire collections from this formation. The few species of Freshwater Gasteropoda described, as probably from this horizon, in the Smithsonian Contributions, (Pal. Up. Missouri,) being still doubtfully referred. This same absence of Gasteropoda is also noticed in all the collections of Jurassic age we have seen from the western countries, 
not more than three or four species haring been obtained beyond those abore referred to.

Among the Cretaceous fossils there are many forms of great interest, especially among the Inocerami and Cephalopoda. Among the former the forms described under the new generic name of Endocostce are interesting as affording light on a group of shells that, although long known, hare not been fully understood, probably owing to the want of more and better material which this collection has afforded, the feature there described having been seen on isolated specimens, poorly preserred.

Among the Cephalopods of the Cretaceous there are some fine examples of the aberrant forms of the Ammonite group, which show very conclusively that a rich field awaits the future collector in this region. In some of the localities of this formation, from which collections have been brought, there appears to be a difficulty in recognizing the divisions of the group, proposed by Messrs. Meek and Hayden, as the fossils of two of the divisions are found intermingling at the same place and in the same layers. The specimens brought from the locality, on Old Woman's Fork of the Cheyenne, are of this character, and there seems to be the same trouble among those from certain parts of Beaver Creek. The collection affords no specimens belonging strictly to the Divisions No. 1 and No. 3, though the beds were observed but not collected from. 
FOSSILS FROM THE PRIMORDIAL ROCKS. 



\section{PLANTAE. \\ Genus PALEOCHORDA.}

PALAOCHORDA PRINA, $n$. $s p$.

Plate 1, fig. 2.

Plants, the remains of which, as preserved on the surface of the rock, consist of narrow, linear, grass-like stipes, coiled or twisted without any regular order, learing by their removal or decomposition flattened depressions of from one line to two lines in width and of an indefinite length, with rounded or obtusely-pointed extremities.

The examples in the collection before us are coiled, forming irregular curres, usually eurolled, but sometimes sigmoidal. The surfaces are smooth and structureless, presenting no marking whaterer, although the substance is usually of a somewhat lighter color than the surrounding rock. The terminations are usually sharply rounded, and the whole appearance is more that of the impression of an Annelid than of a plant, though it is difficult to conceive of the preservation of anything other than a plant to leare such markings. We have referred them to the above genus, presuming them to be congeneric with those figured by Professor McCoy in his Synopsis British Palæozoic Fossils, plate 1 A, fig. 3, although they are not elerated or rounded bodies, but flattened stipes.

Formation and locality. - In the plant beds of the Potsdam formation (probably Upper Potsdam or Calciferous), Head of Red Water Valley, Black Hills, Dakota.

\section{Genus PALEOPHYCUS, Hall.}

Palmophycus occidentalis, $n . s p$.

Plate 1, fig. 3.

Remains cousisting of strong, subcylindrical, flexuous stems or roots, covering the surface of the saudstone. The stems are more or less rounded, although frequently quite flattened, and varying in diameter from one-fourth of an inch to one inch, frequently bifurcating and sometimes dividing into threes. They are commonly interlaced with each other, but do not appear to coalesce, but are simply overlapped; the surfaces, although sometimes quite smooth, are generally marked by indistinct longitudinal pits and ridges of greater or less extent, fre- 
quently occurring of an inch in length, while many are merely short, roughened depressions, which give a corrugated surface to the stems.

Judging from the specimens in the collection, we sbould suppose they often attain considerable length, as on a specimen measuring nearly ten inches the variation in diameter is scarcely perceptible, but occasionally one will be found to terminate in an obtuse point.

This species bears some resemblance to Fucoides duplex Hall, (Fost. \& Whit., Lake Sup., p. 226, pl. A., 23, fig. 1,) but does not present the longitudinal depression along the middle as in that one, except near a bifurcation. It is very similar to $P$. tubularis Hall, from the Calciferous Sandstone of New York; but is less ridged and has a somewhat different mode of bifurcation from any of the specimens of that species which we have seen. If a larger number of the New York species were examined, however, it is possible that the resemblance might be much greater than at present supposed.

Formation and locality.-In the plant beds of the Potsdam formation (probably Upper Potsdam or Calciferous). Head of Red Water Valley, Black Hills, Dakota.

\section{MOLLUSCOIDA. BRACHIOPODA.}

\section{- Lingulepis CUNeOLUS, $n . s p$.}

Plate 2, figs. 5 and 6.

Shells small, rather below the medium size, triangularly ovate in out line, or sometimes subcuneate; rentral valve triangularly ovate, with a sharp somewhat pointed beak, the width and length about as three and four, and the point of greatest length near the lower third of the length of the valve; cardinal slopes abrupt, scarcely convex; basal line rounded at the sides but nearly straight in the middle; surface of the valve strongly convex, becoming almost subangular in the upper part dorsal valve much shorter, proportionally, than the ventral, the length but little exceeding the width; sides and base more rounded and the beak truncate; surface distinctly convex.

Surface of the shell apparently smooth, but usually exfoliated, in which condition a few fine radiating lines are risible.

The shell differs from $L$. pinnaformis $\mathrm{O}$ wen, in size and in the more distinctly cuneate form of the ventral valve. At first sight, it might be taken for the young of that species, but a little critical examination soon reveals marked distinctions in the truncation of the front margin, and especially in the form of the cardinal slopes, which are rounded and never concare, as in almost all rentral valves of that species. In consequence of this latter feature, the beak does not appear so attenuated as in that one, although proportionally quite as long. In the general 
surface characters and form of the valres it corresponds with the genus Lingulepis, although we have not been able to distinguish the muscular impressions.

Were it not for the difference in the size of the shells, we should be inclined to think this might be the speeies figured by Messrs. Meek and Hayden, (Pal. Upp. Missouri, p. 3, Pl. 1, fig. $1 a$ and $b$,) as L. Dakotensis ; but as their figures appear to be of the natural size, we should suppose it to be very distinct, as all the specimens of our shell noticed hare been small, none exceeding one-fourth of an inch in length.

Formation and locality.-In soft, friable sandstone of the Potsdam group, at Ped Cañon Creek, in the. Southwest Black Hills, Dakota.

\section{Lirgutepis PERATtexuatus, $n$. $s p$.}

Plate 2, figs. ₹-9.

Shell spatulate or elongate-ovate, becoming acutely pointed toward the beak; sides below the middle of the length of the rentral valve, rounded; front margin very regularly curred; cardinal slopes straight, or sometimes slightly convex, greatest width a little more than half the length of the rentral valve and sometimes nearly two-thirds as great. Surface of the rentral valve depressed convex, rery slightly subangular along the middle above the lower third of the length, and a little more distinctly so in the upper part. Apex scarcely truncate. Dorsal ralre considerably shorter than the rentral, broadly truncated at the upper end, the line of truncation being distinctly arched. Surface erenly con rex. Structure of the surface of the shell polished, with fine, somewhat lamellose, lines of growth.

The shell in many points closely resembles $L$. pinnaformis Owen, but is a proportionally longer shell and not exceeding one-half the size of the adult specimens of that species. When compared in shape, it is more elongate in front, the lower end of the shell forming a section of an ellipse rather than of a circle as in that one; the cardinal slopes are conrex and the valves proportionally longer, the apex being more elongated in proportion to the size of the body of the shell, but not so narrow. The two species are associated in the same blocks, and the dissimilarity between examples of the same size is so perceptible that there will not be the slightest difficulty in recognizing them as distinct.

Formation and locality.-In greenish-purple sandstone of the Potsdam formation, at the Headwaters of Red Cañon Creek, southwest Black Hills, Dakota. 


\section{ARTICULATA. TRILOBITA. CALYMENIDE.}

\section{Genus CRepicephalus, Owen (?Loganellus, Devine). \\ Crepicephalus (Loganellus) Centralis, $n . s p$.}

Plate 2, figs. 21-24.

Species recognized only by the glabella and fixed cheeks, with a few imperfect fragments of the movable cheeks. The former parts, when united, are somewhat quadrangular in outline, broadest at the base and gently narrowing in front; glabella rounder-conical, higher than wide, the anterior end somewhat sharply rounded; surface highly convex and marked by three pairs of distiuct lateral furrows, which are strongly bent backward in their direction from the margin, and on the larger specimens the posterior pair almost unite in the middle. Occipital fur. row distinct, extending entirely across the base of the head; occipital ring strong, rounded, and in the older individuals supporting a short spine; dorsal furrows well pronounced, extending with equal clearness in front of the glabella. Fixed cheeks broad, more than equaling onehalf the width of the glabella; palpebral lobes small and slightly angular, situated opposite the middle of the glabella; ocular ridges distinct, directed anteriorly in passing from the eye to the dorsal furrow. Frontal limb short, not more than one-third as long as the glabella, one-half of its length formed by the strong, rounded marginal rim and furrow. Facial suture directed gently inward from the front of the eye lobe to the anterior margin, with but little curvature; behind the eye it is directed backward and outward at an angle of from thirty-five to forty degrees with the occipital line of the head, with a slightly sigmoidal curvature, giving an elongate triangular form to the postero-lateral limbs.

There is considerable variation in the form and proportions of the glabella among the different individuals in the collection, the larger specimens being proportionally broader and the lateral furrows much more distinctly marked. On the smaller one figured the furrows are not distinct enough to indicate without exaggeration. The presence or absence of an occipital spine is also noticed, dependent apparently on the same cause. It is possible that the two individuals may belong to different species, but from their great similarity in other respects we feel confident that this is not the case.

This species resembles in some of its characters $C$. (Bathyurus?) angulatus, H. \& W., from the same formation on the west side of Pogonip Mountain, White Pine, Nev., described in Mr. Clarence King's report, but lacks the angular frontal limb of that species, and the facial sutures 
converge in front of the eje, while in that one they are slightly divergent. We know of no other species with which it is closely related, unless it should prove to be more nearly related to Agraulus Oweni, Neek \& Hayden, Pal. Upp. Missouri, p. 9, figs. A, B, C, than we are inclined to believe. There are several particulars in which it differs rery materially from their figures, and also from the description given, that would at once mark it as distinct, if it were not that the imperfect material in both cases tends to lead to error. The difference in the width of the occipital lobe is a rery marked one, and also the length of the frontal limb, while the form of the glabella varies much in being more distinctly conical than in that species.

Formation and locality.-In coarse sandstones of the Potslam formation, at Castle Creek, West Black Hills, Dakota.

\section{Crepicephale's (Logatellus) Plants, $n$. $s p$.}

Plate 2, fig. 20.

Glabella and fixed cheeks, when united, subquadrangular in outline, narrorrest across the ejes and slightl 5 expanding in front, and more abruptly so posteriorly. Glabella rery depressed convex, slightly conical and somemhat squarely truncate in front, the width across the base being equal to about three-fourths of the height above the occipital furrow, and that of the anterior end to about half the height; lateral furrows rery faintly marked, oblique, and extending about one-third of the width from the margin. Occipital furrows not strongly marked, extending entirely across the base of the head; ring narrow, and without spine. Dorsal furrows distinct, but not deep, extending around the front of the glabella. Fixed cheeks wide, more than half as wide, opposite the eyes, as the middle of the glabella. Frontal limb of moderate length, at least as long as the width of the anterior end of the glabella, but its entire extent and anterior margin have not been fully ascertained. Facial suture cutting the anterior border at right angles to the margin of the head and directed slightly inward to the ejes, behind which it is directed obliquely backward, at an angle of about $60^{\circ}$ with the base of the head, to the occipital furrow, behind which it runs more directly outward. Ocular ridges distinct. Palpebral lobes small and situated behind the middle of the head.

The species is only known by the glabella and fixed cheeks, and is remarkable only for its general tlatness and want of prominent characters. There is no known species from the same formation either in the Wisconsin locality or from the more western regions that is so closely related to it as to be readily mistaken. $C$. (L.) quadrans, H. \& W., of Clarence King's report, from the slates abore Call's Fort, North Wahsatach Mountains, is perhaps as closely related as anj, but differs in having the glabella more rounded in front and proportionally broader.

Formation and locality.-Associated in the same beds and locality with the preceding species. 



\section{FOSSILS FROM THE JURASSIC ROCKS.}





\section{RADIATA. \\ ECHINODERMA'TA. \\ ASTEROIDEA.}

Genus ASTERIAS, Linneus.

ASTERIAS ? DUBIUII, $n . s p$.

Plate 3, fig. 3.

Several impressious of a species of star-fish, apparently of the genus Asterias, are present in the collection from a bed of light-red sandstone, which occurs at a horizon of from 80 to 100 feet abore the Triassic red beds.

The specimens are not in a condition to afford a full description of their specific characters. They are of small size, the rays being from three-fourths of an inch to one and one-fourth inches long, measuring from the center of the body. The rays are slender and flexuous, most of them being more or less curved in their direction and elerated along the middle, as shown on a gutta-percha cast taken in a natural mold of a group of three indiriduals. The upper surface is subangular, and in structure they are apparently composed of small nodiform plates, placed in longitudinal rows. The center of the body or disk is marked by an obscurely pentangular depression on the upper surface. None of the specimens show the under side of the body or rays, so that the characters of these parts are entirely unknown.

The species appears to hare been somewhat abundant, judging from the condition in which they are grouped on the sandstone, and although the specimens are obscure and too imperfect for positive determination and description, it has been thought best to designate them by name, as they will undoubtedly prove a characteristic form over a certain region, and of a limited horizon. The sandstone is marked, on the layers in which they are found, by ripple or wave marks, haring a width of about 3 inches, and indicates a near proximity to a shore-line over the area where they were obtained, and that the individuals are probably stranded specimens. A single very imperfect impression of a Lamellibranchiate shell is represented on the same fragments of rock, but too imperfect for determination.

Formation and locality.-In red sandstones of Jurassic age, Park Sands, 70 feet above the red beds, on the east side of Spear-Fish Creek, near its junction with the Red Water, northeast of Crow Peak, Black Hills, Dakota. 


\section{PECTENIDE. \\ Genus PECTEN, Brug. \\ Pecten Newberryi, $n . s p$.}

Plate 4, figs. 12-15.

Shell of moderate size, suborbicular in outline, erect and subequilateral, the height and length nearly equal. Valves depressed-lenticular in a transrerse section when united; their surfaces depressed.convex, except along the sides of the valves near the cardinal slopes, where the surface is elevated so as to form a broad, rounded, fold-like border on this part; with a broad, undefined, shallow depression separating it from the body of the valve. Hinge line short; that of the left valve less than half as long as the shell below; straight or a very little sloping outward from the apex of the valre, which is small, appressed, and not projecting above the line of the hinge. Anterior side of the hinge a little longer than the other, the anterior wing being rounded at the extremity, more than as long again as the height above the body of the valve at its widest part; separated from the shell below by a very shallow, rounded bjssal notch, and along the surface by a scarcely perceptible groove bordering the body of the valve. Posterior wing smaller, triangular, a little obtuse at the outer upper angle, and proportionally somewhat higher or longer on the lateral border than the anterior wing. Surface of the left valve marked, except on the fold and depression bordering the cardinal slopes, by strong, flattened radii, which are variable in strength, size, and distance, and are separated by flattened. interspaces, usually of greater width than the ribs themselres. The surface is also marked by closely arranged, distinctly elerated, regular, lamellose, concentric lines parallel to the outer margin, and coincident with the lines of growth, and are slightly arched backward in crossing the radii. These latter markings also cover the surface of the folds of the cardinal borders and the cardinal auriculations.

A single right valve of small size associated with a number of left valves, on the same block, has the same general form and the same fold-like feature of the cardinal slopes, but appears to be entirely destitute of the radii on the body of the valve; and the concentric markings are also much less distinct and regular than on the opposite valve. The anterior wing is also very small and obtusely triangular, but may have been somewhat mutilated. There can be little if any doubt, however, that this right valve belongs to the same species.

This species may be readily distinguished by the peculiar fold.like feature of the cardinal slopes and the character of the concentric markings, being entirely different in these respects from any other of the genus described from rocks of this age. 
Formation and locality.-In reddish and buff colored argillaceous limestones of Jurassic age, at T_— Spring, west of the Black Hills of Dakota.

\section{Pseudonorotis (Eumicrotis) orbiculata, $n . s p$.}

$$
\text { Plate 3, figs. 17-19. }
$$

Shell of moderate size, orbicular in outline, nearly equilateral and subdiscoid. Left valve depressed-convex, most rotund just below and anterior to the beak; beak small, full, slightly incurved, and projecting somewhat abore the cardinal border. Anterior wing very short, almost obsolete, the anterior end regularly rounded from its extremity to and along the basal margin; posterior wing of moderate size and com. pressed, shorter than the shell below, the posterior margin rounding backward from its extremity to near the middle of the length of the valre, thence somewhat regularly rounded to the base. Surface of the valve marked by numerous unequal, slender, and slightl 5 elevated radii, which are separated by wider flattened interspaces; also by irregular concentric strix of growth, which often give a knotty or roughened surface to the radii where crossing them, especially toward the posterior border and near the outer margin. Right valve less convex than the opposite one, with a smaller inconspicnous beak, which does not project beyond the cardinal line. Anterior side of the hinge line characterized by a small and very obscure wing, which is reduced to a mere point, reaching to not more than one-third of the length of the very short anterior side of the hinge. The wing is separated from the body of the shell below, as in others of this division of the group, by a narrow and rather deep groove, but not by a distinct sinus. Posterior wing longer and compressed, but not extending to more than half the length of the body of the shell below. Surface of the ralre marked, in all cases observed, by fainter radii than the left valve, but otherwise of similar character.

This species is closel $y$ related to $P$. $(E$.) curta, Hall, but is much larger, several of the individuals measuring seven-eighths of an inch in length, and one specimen measures nearly an inch; while those of that species seldom attain to more than two-thirds of that size. The shell is also much less oblique; less convex; the radii sharper and not usually so distant, although in this latter feature they both differ very materially among the different individuals, and the right valve is also distinctly marked by the radii, which is not the case in that one.

Formation and locality.-In calcareous clays of Jurassic age, ranging about 20 feet above the red beds, at Red Water Valley, Black Hills, Dahota. 


\title{
FAM. MYTILIDE.
}

\section{GENUS MYTILUS, Linn.}

\section{Mytulus Whitei, n. sp.}

\author{
Dlate 5, figs. 9-12.
}

Shell of moderate size, trapezoidal in outline, very oblique; hinge line slightly arcuate, as long or a little longer than the distance from the apex to the postero-basal extremity; anterior or byssal border long, distinctly concave from the apex of the beak to the junction of the basal border, the general direction being at an angle of about $45^{\circ}$, or within $45^{\circ}$ with the cardinal line; posterior margin a little more than half as long as the shell and nearly parallel to the anterior border, or slightly converging toward the base; basal margin short and more or less rounded, somewhat variable in different individuals. Beaks small, pointed, terminal and incurred, with a short but distinct area-like space beneath them; umbones prominent, subangular, and with a slightly flattened or concave space on the anterior side, just below the apex of the beak. Umbonal ridge elerated, strongly arcuate and subangular, the surface of the shell sloping rapidly to the posterior and postero-cardinal margins. Anterior slope of the shell nearly or quite vertical, or sometimes a little concare near the middle of the length.

Surface of the shell marked by numerous strong but very irregular varices of growth, which give to the shell an extremely rugose appearance. Between the rarices the surface is marked by fine lines of growth. No radiating lines or other surface markings, beyond those described, can be detected. Substance of the shell thick and strong.

The shell is a strongly marked and very characteristic species, and judging from the fragments in the hand specimens of rock, must have been an abundant form in a certain layer at the locality where collecter. We know of no American species of the genus having anj close resem. blance to this one.

Formation and locality.-In rocks of Jurassic age, associated with other Jurassic fossils, near Sun-Dance Hills, Northwestern Black Hills, Wyoming.

\section{Genus TrapeZIUM, Humph. (= Cypricardia, Lam.).}

\section{Trapezium Bellefourchensis, $n$. $s p$.}

Plate 5, figs. 1-4.

Shell small, transversely elongate-quadrangular, the length being from two and a half to three times greater than the height; dorsal and basal margin subparallel, the former very slightly arched and the latter scarcely concave, except in the older individuals, the smaller and me- 
dium-sized individuals being usually a little eurved upward toward the posterior end; beaks small, nearly terminal, rounded on the umbones and rery slightly incurred; posterior extremity truncate, in the older specimens rather squarely so below, and rounding forward to the extrem. ity of the hinge-line above. In the smaller individuals it is narrower, somewhat sloping from above or obliquely truncate. Anterior end very slightly prolonged below the middle of the height and excavated beneath the beaks. A narrow linear escutcheon of considerable length is seen on many of the separated valces. Anterior muscular impression rather large and strongly impressed, as shown by the strong markings on internal casts; posterior impression not distinguishable; pallial line faint, and the space within the limits often marked by radiating lines as in the recent forms of the genus.

Surface of the valves ventricose, with a distinctly angular umbonal slope in the larger specimen, but often obtusely rounded in the smaller ones. A broad but rather faint depression runs obliquely backward from the beak to the middle of the basal border on many indiriduals, but is not always present. Surface of the shell marked br irregular concentric lines of growth parallel to the margin of the valre.

The species is closely allied to a form described by Mr. Meek (in MS.) uuder the name of Trepezium (Pachymya) truncata, but is proportionally very much more elongated than the specimens which are so labeled in the collection at the Smithsonian Institution. The shells have been exceedingly abundant in certain lnjers, being deusely packed together, so that it is impossible to separate the indiriduals. They are quite rariable in form at different stages of growth, the younger shells being transversely elongate-ovate, narrowed and rounded, or very obliquely truncate from above posteriorly, and becoming almost squarels truncate behind in the older specimens, the slight sinuosity of the basal margin being hardly noticeable until they attain to near their adult size.

Eormation and locality.-In a hard and somewhat siliceous limestone of reddish color, at a level of 350 feet above the Triassic beds east of Belle Fourche, Black Hills, Dakota.

\section{TrapezIUM SUBEQUALIS, $n . s p$.}

Plate 5, figs. 5-8.

Shell small, trausversely elongate-subelliptical, about twice and a half as long as high, or nearly so. Valves somewhat ventricose, with large tumid beaks situated a little nearest to the anterior end, and projecting abore the general line of the hinge; hinge-line, posterior to the beaks, about half as long as the entire length of the shell, straight, but gradually declining to the extremity; posterior end of the shell very obliquely truncate, being much the longest below the middle of the postero-basal angle; anterior end shorter, slightly contracted in front of the beaks, but rounded at the extremity and broader than the opposite end; basal 
margin straight or very slightly convex in the middle, and strongly rounded upward toward each extremity. Body of the shell often distinctl $\mathrm{v}$ angular along the posterior-umbonal ridge and the postero-cardinal slope quite abrupt; some individuals, however, are obtusely rounded on the umbonal ridge. Surface of the shell marked by rather strong concentric ridges of growth, which are crossed, on the rounded anterior end and middle of the valve, by extremely fine radiating striæ, only detected near the basal portion of the larger individuals by the aid of a moderate magnifying power.

There may be some little doubt as to the true generic relations of this shell, but it possesses so many of the features of Trapezium that we have not hesitated to refer it to that genus; the almost subcentral and somewhat prominent beak forms the strongest point of difference. It differs in this respect from th e preceding species, as also in the general form of the valves, and in the surface markings. The shells of the two species hare nearly the same dimensions, and in their mutilated and imperfect condition, as seen imbedded in the rock, may readily be confounded, but the more prominent beaks and longer anterior end of this one will at once distinguish them.

Formation and locality.-In a hard white sandstone of Jurassic age, associated with Pseudmonotis curta just above the Triassic red beds, at Red Cañon Creek, Black Hills, Dakota.

\section{Family uncertain.* \\ Genus PleuromyA, Agassiz.}

\section{Pleuromya Newtoni.}

Plate 5, figs. 19 and 20.

Shell of moderate size, trausversely subovate or triangularly ovate, the greatest height being across the valve nearly on a line with the beaks. Valves strongly convex near the anterior end, and in a cardinal view acutely wedge-shaped, thickest opposite the beaks and rapidly decreasing posteriorly. Beaks large, strong, enrolled, and approximate, situated at, or within, the anterior third of the shell and projecting largely above the the cardinal line. Hinge-line not exceeding onehalf the length of the shell, distinctly arched; anterior end obliquely subtruncate, longest below at its junction with the basal margin, and in some cases the anterior slope is distinctly flattened. Posterior end

" The family relations of this shell, as well as some others herein described, are not yet satisfactorily determined, and we do not like to refer them to a family to which we feel certain, from their characters, as far as known, they have no resemblance or affinity; we rather prefer to leave them in doubt, and as subjects for future investigation. The reference of Pleuromya and Myacites to the same family with Anatina we deem unnatural, as from the character of the shell, and the consequent habits of the animal, they must have been very far removed from each other in structural features, and these we deem the ny sure and reliable means of classification. 
narrowed, the postero-cardinal margin rapidly declining from the extremity of the hinge-line to the longest point of the ralve, which is narrowly rounded and at about the middle of the height; basal margin very slightly constricted, or emarginate, just within the anterior third of the length, by a faint sulcus, which passes from the surface of the umbo to the base of the shell; posterior to this it is strongly convex, and as it approaches the posterior third of the length is more strongly rounded upward to the extremity. Body of the ralre convex, most rentricose on the umbones and along the middle of the valve; anterior umbonal ridge obtusely angular; anterior slope abrupt and sometimes flattened obliquely; posterior umbonal ridge scarcely defined or broadly rounded. Immediately behind the anterior umbonal ridge a broad undefined sulcus passes across the valre, slightly modifying the direction of the concentric lines. No appearance of escutcheon or iunule exists, nor of an external ligament.

Surface of the shell marked by numerous irregular concentric undulations, which are usually broad and undefined, but on some indiridnals hare a slightly sharper character. The general surface beyond these undefined undulations appears to hare been smooth, and we should suppose from its character that it had been semipolished. Substance of the shell moderately thick. The features of the hinge and interior hare not been fully ascertained; there appears, howerer, on a left ralve a strong tooth-like process of considerable height, and in front of it a deep triangular pit, probably ligamental.

This species differs from Myacites (Pleuromya) subcompressa, Meek (Sixth An. Rept. U. S. Geol. Surr. Territories, 1872, p. 472), in being proportionally longer; more distinctly ovate or less triangular. The anterior end being of greater length in proportion to the rest of the ralve, the beaks are larger and project farther abore the cardinal line; the body of the shell is less flattened and the surface less strongly narked.

Formation and locality.-In shaly limestone of Jurassic age, on top of the highest hills two miles south of Belle Fourche, Black Hills, Dakota.

\section{TANCREDIA CORBULIFOMIS, $n . s p$.}

Plate 6, figs. 5-3.

Shell small, seldom measuring more than half an inch in length, rery broadly orate in outline and largest on the posterior side of the beaks, the length being a little more than once and a half the height; the beaks large and full, slightly enrolled, almost central and strongly inclined toward the anterior part of the shell. Anterior end narrowed, strongly constricted in front of the beaks, giving a somewhat concare anterocardinal line, the extremity acutely rounded; posterior end broadly ronnded, and the postero cardinal line convex to near the beaks; basal line regularls carred except at the posterior part where it becomes a 
little more abrupt. Body of the valre strongly courex, almost inflated on the umbo.

Surface of shell apparently smooth, but uncler a magnifier showing faint, scarcely defined, lines of growth.

The species differs from $T$. inornata, M. \& H., in its smaller size, more inflated valves, proportionally larger and more prominent beaks, and greater inequality in size of the anterior and posterior parts of the shell.

Formation and locality.-In sandy and somewhat shaly limestones of Jurassic age, 350 feet abore the red beds of the Triassic, east of Belle Fourche, Black Hills, Dakota.

TANCRedia BUlbosa, $n . s p$.

Plate 6, figs. 1-3.

Shell very small, the larger indiriduals not measuring more than threeeighths of an inch in length, by a height of one-fourth of an inch ; very broadly orate in outline, being inflated and globuliform in the middle and posteriorly, and attenuate, narrowed and compressed toward the anterior extremity. Beak strong, inflated, curving anteriorly, and situated a little to the anterior of the middle of the shell; anterior end acutely rounded, the sides of the shell abruptly compressed by a broad, undefined, constricting sulcus, or depression, which passes obliquely across the valve from in front of the beaks to the basal border, in which it forms a distinct emargination; posterior end broadly rounded, and the posterior cardinal line strongly convex; antero-cardinal line constricted in front of the beaks, and concave between them and the anterior extremity; basal line very convex for a little more than twothirds of the length from the posterior end, where it becomes emarginate at the base of the oblique sulcus or depression, which crosses the anterior part of the valve. Surface semi-polished, and under a magnifier showing fine lines of growth.

The species resemble $T$. corbuliformis herein described, but is a smaller shell, seldom occurring of more than half the usual length of that one, and is much more extreme in the unequal size of the anterior and pos. terior parts of the valve, besides being much more globose in form, and having the anterior oblique sulcus of the valve much more strongly marked.

Formation and locality.-In rock of Jurassic age associated with $T$. corbulifor mis and $T$. inornata at the same locality.

TANCREDIA POSTICA, n. sp.

Plate 6, fig. 14.

Shell small, transversly orate, the height and length being about as three to five. Valves very ventricose, becoming tumid near the beaks and on the postero-cardinal part. Beaks large, and but little elevated 
abore the cardinal line, slightly enrolled and directed forward, situated at about one-third of the length from the anterior extremity; antero. cardinal line abruptly declining in front of the beaks to the middle of the height of the valve; anterior end narrow and sharply rounded; posterior end very broadly rounded, and the postero-cardinal and basal margins subparallel behind the beaks, the extreme height of the shell continuing to the posterior end; antero-basal line strongly curving upward to the anterior end of the shell. Surface of the valres appar. ently smooth.

The shell differs from any of the preceding species in the greater length and proportiouate size of the posterior portions of the shell, in the situation of the beaks, and in their strong anterior inclination, the others being much more erect than those of this species. It will be readily recognized by the inflated valves, subparallel cardinal and basal margins, and short anterior end.

Formation and locality.-In shaly limestones of the Jurassic formation east of Belle Fourche, Black Hills, Dakota, associated with the preceding species. -

\section{FAM. VENERIDAE. \\ Gendos DOSInIA, Scopoli.}

\section{DOSINIA JURASSICA, n. $s p$.}

Plate 5, figs. 21-24.

Shell of moderate size, subcircular or rery slightly transverse in form, and for the genus quite rentricose, with rather large, prominent beaks. Cardinal line arcuate but less curred than the general circle of the shell, while the anterior end is more sharply curved and slightly angular, and the posterior portion from the extremity of the hinge to the basal border rery slightly flattened or truncate. Beaks anterior to the middle of the valve, directed forward and approximate at their apices ; lunule small and rery slightly impressed ; ligament proportionally long, but narrow, the shell at its margins slightly incurved. Body of the valve ventricose, most gibbous on the umbones and below, while anteriorly and posteriorly the shell is more compressed; umbonal ridges not defined.

Surface of the shell smooth, with a few obsolete or faintly-marked concentric irregularities, but no defined rarices; fine concentric lines of growth are seen on the perfect shells under an ordinary magnifier. Inner margins of the valres smooth; muscular impressions large but faintly marked, submarginal; pallial line deeply sinuate, the apex of the sinus being directed toward the beak of the shell.

The shell is a well-marked species of Dosinia so far as the characters hare been ascertained, but the hinge structure has not been seen, none of the casts being in a condition to show the teeth. The casts are quite 
abundant on weathered specimens where they have apparently been subject to the percolating action of mineral raters, which has partially destrojed them.

Formation and locality.-In Jurassic rocks at the top of the highest hills, two miles south of Belle Fourche, and at a horizon of 350 feet above the Triassic red beds, east of Belle Fourche; and also on the east side of Spear-fish Creek, near junction with the Red Water, northeast of Crow Peak, Black Hills, Dakota.

\section{FAM. PSAMMOBIIDE. \\ Genus PSAMMOBIA, Lam.}

Psamiubia ? prematura, n. $s p$.

Plate 5, fig. 31.

Shell small, transversely èlongated, with parallel dorsal and basal margins, the length equaling a little more than twice the height. Valves very depressed-convex and distinctly gaping at each end. Beaks small and inconspicuous, compressed, situated a trifle nearest the anterior end ; the antero-cardinal line gradually declining with a very slight convexity to the narrowly-rounded anterior end, basal margin straight for more than half the length of the shell, rounding upward anteriorly and posteriorly; postero-cardinal line a very little lower than the apex of the beak, behind which it is straight to near the extremity of the shell; posterior extremity reaching its grea test length considerably above the middle of the valve, the margin being directed obliquely forward below to the end of the basal line. Surface of the valve regularly curved from beak to base and from the posterior umbonal ridge forward to the anterior extremity of the shell, forming nearly a level line; posterior to the umbonal ridge the shell is depressed, forming a broad oblique sulcus extending from behind the beaks to the posterior margin of the shell. Muscular markings faint. Pallial line not profoundly sinuate, but distinctly emarginate behind. Hinge and teeth unknown.

The species is only recognized by single valres, but the form is so precisely like that of some of the recent Psammobias that it seems unnatural to refer it to any other genus. The parallel dorsal and basal margins and the form of the posterior slope will readily distinguish it from any other shell in the rocks from this region.

Formation and locality.-In the sandy limestones of the Jurassic beds east of Belle Fourche, Black Hills, Dakota.

\section{Genus NEARA, Gray.}

NEARA LONGIROstra, $n . s p$.

Plate 5, fig. 35.

Shell very small, scarcely exceeding one-fourth of an inch in length ; transversely elongate-ovate or clavate, widest anterior to the middle, 
and narrowed behind, a little more than twice as long as high. Valres very conrex, becoming inflated near the middle and on the umbones. Beaks proportionally large, erect, strongly projecting abore the hinge line, and situated in front of the middle of the length; anterior end large and broadly rounded, somewhat excavated beneath the beaks; posterior end narrowed, elongate, and rery slightly recurved, and obliquely truncate above the umbonal angle; basal line strongly convex, more distinctly so just in front of the middle opposite the beaks, and broadly constricted behind; posterior umbonal ridge very faintly angular, and the cardinal slope rather abrupt.

Surface of the shell marked by a few concentric lines of growth, and crossed on the anterior and middle parts of the shell by a few proportionally strong, elerated, radiating ridges, to the number of eight or nine, with wider flattened interspaces.

The species is small, and being preserred in a friable sandstone, the surface characters are not clearly defiued, nor can any of the hinge or any other internal features be seen.

Formation and locality.-In white sandstones of Jurassic age, in Red Water Valley, Black Hills, Dakota; associated with Pseudomonotis curta, Tancredic Warrenana, and other Jurassic fossils.

\section{FAM. GASTROCHENIDE.}

\section{Genus SAXICAVA, Bellevue.}

\section{Saxicava Jurassica, n. $s p$.}

Plate 5, figs. 25-30.

Shell small, elongate-subcylindrical, with subparallel dorsal and basal margins; beaks approximate, distinct, situated near the anterior end and flattened on the exterior surface; umbonal ridge strongly marked and subangular, placed behind the middle of the ralre. Anterior end narrowed and very slightly excarated below the beaks; posterior extremity wider and rounded on the margin, the sides being laterally compressed; basal margin very gently concare in the middle of its length. Body of the valves rery broadly sulcated between the anterior end and the umboual ridge, and somewhat inflated along the latter feature posterior to the middle of the length. Surface of the shell rather distinctly marked by concentric lines parallel to the margin, which are elevated and irregular, but not lamellose; also by a few strong undulations of growth. Just below the hinge-line, on the postero-cardinal border, the surface strix are slightly bent and the surface of the shell rery slightly angular. Internally, as seen on casts, the anterior muscular impression is narrow, and situated along the antero-basal margin. The pallial line appears to be strongly sinuate, and the dorsal margin shows eridence of a rather strong ligament. The casts of the burrows, as seen in the rock, are almond-shaped, or very elongate-orate. 
A small fragment of argillaceous rock in the collection was found to contain quite a number of the burrows, and, on being broken, a few were found with the shells in position; but in an effort to develop them from the matrix, the shell is usually removed from the casts, although some of it is at times retained, and it is from this rather imperfect material that the description has been drawn. The general form of the shell and also the external texture would seem to ally them with the angular group of the genus Lithodomus, characterized by $L$. gruneri Phillipi, but the sinus of the pallial line would seem to forbid this reference.

Formation and locality.-In rocks of Jurassic age, at a horizon of 350 feet above the red beds of the Triassic, at Red Water Valley, Black Hills, Dakota. 
FOSSILS OF THE CRETACEOUS. 



\title{
MOLLUSCA. LAMELLIBRANCHIATA. \\ FAMr. PTERIID E, Meek.
}

\author{
Genus PTERIA, Scop. \\ Pteria (Pseudopteria) sublevis, $n$. $s p$. \\ Plate 7, fig. 6.
}

Shell small, erect, sub-rhomboid or sub-ovate in outline, left valve depressed-convex, most ventricose on the umbo and toward the beak, near which it becomes subangular. Hinge line shorter than the length of the shell below, and about two-fifths as long as the height; anterior wing minute, obtusely pointed, posterior wing moderate in size and convex, scarcely separated from the body of the shell by a slight almost imperceptibly depressed line; anterior side of the shell gradually receding from below the anterior wing to the basal border, which is rather sharply rounded, and the postero-basal margin a little more sharply rounded than the basal.

The surface of the valve in all the specimens seen is much exfoliated, so that the surface features are not positively known, but it has, apparently, been quite smooth. The substance of the shell remaining on the specimens is highly nacreous.

Sereral individuals of the left valve have been noticed in the collection, but none of the right have been recognized. Those seen all have the same character, and one of about the same size, being a little less than three-fourths of an inch in length by about half an inch in width. It most nearly resembles in form $P$. (Pseudopteria) fibrosa, M. \& H. (Paleont. U. S. Geol. Surr. Territ., p. 36, pl. 17, fig. 17), but differs entirely in the surface features, being entirely destitute of the faint plication of that species.

Formation and locality.-In limestone of Cretaceous age, No. 4, Old Woman's Fork, Black Hills, Dakota.

Among the collections from the Fort Pierre group there are large numbers of Inocerami, representing several of the species and varieties recognized by Mr. F. B. Meek, in his excellent work on the Upper Missouri Cretaceous formations, just issued by the Department of the Interior. Bat notwithstanding the careful manner in which these forms have been described and figured by that author, we find great difficulty 
in arriving at any very satisfactory conclusions as to the limits of species when so large a collection is examined. The species, as figured in the above-mentioned work, appear distinct enough, and the lines of demarka. tion well drawn, when a few individuals only are before one, but among the collections in hand we find the boundaries crossed in every direction, so that we are at a loss in many cases for characters by which to separate the different forms there indicated, while there are still others among them so entirely different from any of those described and figured that we are very reluctantly compelled to consider them as entirely distinct.

Among the forms representing those given under the names $I$. Vaunxemi, I. proximus, and I. proximus, var. subcircularis, and also as 1 . convexus and I. Sagensis, var. Nebrascensis and I. Balchii, we find such gradually connecting links as to make it extremely difficult if not impossible to draw lines of distinction between them. Again, those resembling the forms given under the names $I$. Cripsii, var. Barabini and I. tennilineatus, are similarly united.

The forms which we had referred to 1 . Sagensis and 1. Nebrascensis of Owen, vary so greatly in the posterior prolongation of the shell and also in the direction of the basal margin as to defy all attempts to classify them by their form, and in the relative degree of convexity and the comparative distance of the surface undulations they are eqally variable and-unsatisfactory. We find also that the relative projestion of the beaks and the width of the cartilage area, as well as the distance of the beaks from the anterior end, is subject to great variation. Although in the collection before us there are but few individuals which retain the right and left valves in contact, still of many of them we hare both valves of similar size and form from the same locality, and we find that the difference in convexity between the two valves is not, in any case, very great, and often scarcely perceptible. The beak of the left valve is usually larger and projects more beyond the line of the hinge than that of the right, and the cartilage area is a little wider. Perhaps if the real surface features of the shells were preserved on the specimens more reliable characters for specific distinction might be presented, but the fibrous coating is almost always absent, being generally left in the matrix and not collected, or perhaps in many cases remored by some action of decay before the shells are finally imbedded in the rocky sediment, so that in collections it is seldom that any part of this layer is retained on the specimens, except a little around the beaks or along the hinge margins. Owing to these difficulties, the same that Mr. Meek has found to exist among his specimens, and also to the impossibility of giving a sufficient number of figures to show fully and clearly the variations which we have found among the examples in hand, we shall be obliged to follow very nearly the same specific limits which that author has found desirable, though we must confess that in some cases we should prefer rather to consider some of the forms found associated to- 
gether in the same localities and presenting only slight differences, as one and the same species, than to identify these far western forms with species described from Europe, as has been done by so many authors. We do not dispute their great resemblances, but beliere them to be rather representative species than equiralent forms.

\section{INOCERAMUS PERPLEXUS, $n$. $s p$.}

Plate 8 , fig. 3 , and plate 10 , figs. 4 and 5 .

Shell rather below the medium size, erect, truncate, suborate in outline, shortest at the hinge-line, and gradually expanding to below the middle of the height; valres conrex; beaks terminal, slightly inclined forward, pointed, and incurved; hinge-line short and straight, not exceeding two-thirds of the length below in any of the examples seen; anterior border straight or very slightly concare for more than half the height of the shell, where it unites with the deeply rounded basal border; posterior margin of the shell gradually widening from the extremity of the hinge-line to the point of greatest width, in an anteroposterior direction, which is rather below the middle of the height, where it unites in a regular curre with the basal margin. Valres most strongly conrex along the umbonal ridge, which is situated nearest to the anterior side of the shell and slopes gradually to the posterocardinal portion, where it becomes almost flattened; while the anterior border is vertical, or sometimes slightly concare, for more than half the depth of the ralive.

Surface of the shell marked by strong, irregular, concentric folds or undulations, parallel to the margin and passing off on the vertical anterior border. Substance of the inner layers highly nacreous. Fibrous coating, when preserred, apparently thin.

This species is somewhat remarkable for its erect form and strong concentric undulations. In form it resembles the specimens of $I$. fragilis Hall and Meek, given hy the latter author, (Pal. U. S. Geol. Surv. Territ., p. 42, figs. 12 ), but in the surface characters it is entirely distinct from that species, and, when compared with examples of that species having the characters of the original specimen, is very readily distinguished. It also somewhat resembles $I$. Ellioti Gabb from the Cretaceous sandstones of San Francisco Harbor, Cal.

Formation and locality.-In concretionary limestone at the top of shales of Cretaceous No. 2, on the Belle Fourche, about ten miles west of Crow Peak, Black Hills, Dakota.

\section{Endocostea, newo gen.}

Shell resembling Inoceramus, being bivalve, with both sides convex, but more or less nnequal, and composed of two layers, an outer vertically fibrous coating and an inner nacerous or pearly lining; hinge-line straight, edentalons, with a narrow linear external cartilage area on 
each ralre. Valves provided with an oblique internal rib, passing from behind the beaks, along the postero-cardinal slope, toward the postero basal margin, marking the position of the posterior muscular imprint. Other muscular marking unknown. Type, $=E$. Typica, Whitf.

We have not been able to detect the anterior muscular scar or pallial line, except the latter as an irregular transverse line of small tubercles across the beak of internal casts in several cases, and a slight, curving ridge, faintly marked on a smaller number of examples, passing from the apex along the anterior side for a short distance. The genus differs from Inoceramus, so far as yet known, only in the existence of the internal rib. The species now known are $E$. alveatus = Inoceramus alveatus, Morton; E. impressus $=I$. impressus, D'Orb. E. sulcatus $=I$. cripsii var. Sulcatus, Roemer; and E. typica, Whitf., herein described.

Endocostea TyPICA, $n . s p$.

Plate 9, figs. 1-7.

Shell of medium size, transversely subovate, oblique, and slightly inequivalve, the right side being the largest in the only example where they are preserved in contact. Valves strongly ventricose at the ante. rior end and on the anterior part of the umbonal region, becoming more compressed and attenuate behind and along the posterior cardinal portion, sometimes strongly depressed and concave between the cardinal line and dorsal slope. Hinge-line straight, often two-thirds as long as the shell below, and slightly rounded at the extremity. Beaks small, incurved, projecting but little above the cardinal line, and situated near the anterior end, but not quite terminal. Anterior end short, sharply rounded at the antero-cardinal angle, and extending a little forward below for about half the height of the valve, when it rounds backward to the basal line, the upper part forming, with the cardinal line, an angle of about $95^{\circ}$ to $100^{\circ}$. Posterior end nearly equal to, or narrower than, the anterior, and more sharply rounded, most strongly from below. Basal line forming nearly half of an ellipse, or semiovate, the widest part varying from in front of to behind the middle of the length, in different individuals. Surface of the valves usually marked by very distinct concentric undulations, though sometimes they are only moderately developed. Oblique internal rib strongly marked, narrow and pointed near the beak, and gradually widening and deepening posteriorly, the concentric furrows distinctly crossing and leaving, on the deeply concave channel of the casts, corresponding depressions. Inner layers of the shell highly nacreous; outer prismatic layer very thin.

This species resembles Inoceramus Barabini, as it is recognized in the same region, in the general form and in the subcuneate anterior end of the shell; but the concentric furrows are generally more distinctly marked and regular. It is readily distinguished by the oblique sulcus and by the opposite valve being the largest, if the example above referred to, and figured on the plate, is rightly interpreted. 
We have great doubts of the identity of the restern forms with $I$. Barabimi Mortou, from Alabama, and are inclined to believe they would be more naturally classed under a distinct, name, as formerly done by Messrs. Meek \& Hašden.

Formation and locality.-In limestone of the Fort Pierré group, at Old Woman's Fork of the Cheyenne Rirer, Black Hills, Dakota, where they occur very abundantls, densely packed together in the rock, and possessing the specific characters and the oblique sulcus in a remarkably coustant degree.

\section{MCULANID AE.}

\section{Genus NUCULANA.}

\section{Nuculana subequilatera, $n . s p$.

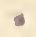 Plate 11, figs. 3 and 4.}

Shell of small size, transsersly elongate-suborate, with large, prominent, suberect beaks which are placed a little in advance of the middle of the length, and are slightly incurved, but comparatively distant. Valres conrex, as seen on the casts, rentricose in the middle and below the beaks, and compressed toward the extremities; more particularly so posteriorly; hinge-line abruptly bent between the beaks, the opposite sides forming an angle of about $140^{\circ}$, the posterior side slightly recurring in the outer part; anterior end of the shell sharply rounded; posterior extremity acutely rounded near the extremity of the cardinal line, and rapidly sloping forward below to the basal margin, which is broadly curred and almost straightened in the middle.

Surface of the shell unknown; hinge-plate marked by a large number of comparatively long, slender teeth, minute in the middle, and gradually increasing in size and length outwardly; about twenty may, with difficulty, be counted on the posterior side of the beaks, and about. eighteen on the shorter side. Cartilage pit small; muscular imprints faintly marked. No sinus can be detected in the pallial line.

The species seems to be nearly related to Nucula (Nuculana?) equilateralis, M. \& H., but the beaks are not central as in that species, but are situated at about two-fifths of the length from the anterior end, and the teeth are decidedly not obtuse, but on the contrary are very slender, as seen on the casts.

Frmation and locality.-In Cretaceous rocks on the Cheyenne River, near French creek; supposed to be rery near the top of the Fort Pierré group. 


\title{
FAM. CRASSATELLID A. \\ Genus CRASSATELLA, Lam.
}

Crassatella subquadrata, $n . s p$.

\author{
Plate 11, fig. 12.
}

Shell small, subquadrangular in outline, with thin, compressed valves and not prominent beaks, which are situated within the anterior third of the length; length of the shell exceeding the height; basal margin broadly rounded; anterior end short and narrowly rounded; posterior end broad and rounded truncate; posterior hinge-line straight and subparallel to the basal margin. Surface of the shell unknown. Muscular impressions small; the posterior one situated close beneath the extremity of the hinge-margin, and the anterior scar submarginal. Pallial line not distinctly marked; margin of the valves crenulate.

The only specimen of this genus recognized among the collections from the Black Hills is a small internal cast, answering to the abore description, and apparently a true Crassatella. Although the extremity of the hinge-plate has not been seen, the cast has all the features usually possessed by easts of the typical forms of the genus.

Formation and locality.-In Cretacons beds on the Cheyenne River; probably from the Fort Pierré group.

\section{CYPRINID A.}

\section{Genus SPHÆRIOLA.}

\section{SPH AERIOLA TRANSVERSA, $n . s p$.}

Plate 10, figs. 14-16.

Shell of rather large size, subsphæroidal, a little transverse, or louger than high, exclusive of the projection of the beaks, the outline of the margin of the valve being slightly oblate or transversely broad-oval, and nearly symmetrical. Valves highly inflated on the central area and umbones, with strong, highly-clevated, strongly-incurved, subcentral beaks, which are slightly curved forward and subangular on the nm. bonal ridges.

Surface of the shell marked by sublamellose, concentric lines of growth, which form strong distant undulations in some cases toward the extremities of the shell.

Internally the muscular impressions are large and subcircular, and the pallial line simple and entire. The cardinal teeth, as obtained by a gutta-percha mold from a natural cast, consist of two tuberculiform teeth beneath the beak, and the laterals are represented by a strong oblique fold or ridge passing from near the beak to within a short dis- 
tance of the posterior borler of the hinge-plate, where it is marked or divided by an impressed pit, which may be accidental.

Compared with S. obliquata Meek, this shell is more equilateral, the beaks more nearly central, and the shell less oblique. It differs from S. Moreanenris of the same author in having much larger beaks, more strongly enrolled, and the shell is also more transrerse.

Formation and locality.-In ferruginous sandstone of Cretaceous No. 5. Ou the Chesenne River, near Old Woman's Fork, Dakota.

\section{ZELLINID A.}

\section{Gexus LIOPISTHA, Meek.}

Subgenus CYMELLA, Meek.

\section{I.eiopistha (CyMella) MeEki, $n . s p$.}

\section{Plate 11, figs. 27 and 23.}

Shell of moderately large size, transrersely oral in outline, about once and a half as long as high. Valres rery convex, with large, tumid, incurred beaks, which are located a little more than one-third of the entire length from the anterior end of the shell, and are considerably elerated abore the cardinal line; anterior and posterior ends of the valve broadly and nearly equally rounded, and the basal line between the longest points of the shell forming a very regular and nearly symmetrical semioval curre; cardinal line sloping gradually on both sides of the beak, the anterior side marked by a narrow, lanceolate, lunule-like depression, and the posterior side by a larger, broader area, bordered by an elerated ridge. Concentric undulations of the surface strong and distinct, contiuuing their sharpness to the margins of the cardinal depressions, and gradually increasing in strength with the increased size of the shell to below the middle, bejond which point they become flattened and fainter; about trenty-seven may be counted on the entire surface. The concentric undulations are crossed by comparatively strong radiating costre, which do not mark the depressions between the nudulations, but exist only on their flattened surfaces. The radii are strongest on the central parts of the shell and become gradually finer and closer toward the lateral extremities, and are risible on the anterior end to the margin of the cardinal depression, but on the posterior end are not seen to exist quite so far. The crests of the radii appear to have been marked by a row of minute puncta, seen only under a magnifier, three and four existing to each undulation. The surface of the shell is also marked by fine, somewhat wrinkled, concentric lines of growth, especially on the larger parts of the ralre, but apparently confined to the outer coating of the shell, and presenting the appearance of a thick epidermis.

We were at first inclined to consider this as P. undulata M. \& H., but on strict comparison with Mr. Meek's description in the Pal. of the U. S. 
Geol. Surv. Territ., which we have just received, have concluded it to be a different species. It differs, first, in the greater size and more robust habits, also in the comparatively stronger undulations, aud in having the radiating costæ continuing to the anterior end if not to the posterior also. The outline of the shell also differs somewhat.

Formation and locality.-In (Uretaceous strata at Dead Man's Rapids, Upper Missouri. Probably of No. 5.

\section{FAN. ANATINID \&.}

\section{Genus THRACIA, Leach.}

THRACIA sUBgraCiLIS, $n . s p$.

Plate 11, figs. 29 and 30.

Shell small, transversely orate and slightly inequivalve, valves conrex, rentricose in the middle, but becoming quite compressed and almost constricted behind; anterior part large, forming nearly or quite four-fifths of the entire bulk of the shell, the extremity rounded; basal line full in front of the beaks and constricted or sinuate behind; posterior end narrow and subtruncate; anterior cardinal line long, nearly on a line with the beaks and very slightly convex; posterior to the beaks the cardinal line is constricted and narrowed; beaks small and compressed, appearing as if directed backward.

The surface of the only specimen is imperfect, the shell being in great part removed, but where preserved is marked by concentric lines of considerable strength, approaching in character to undulations rather than striæ. The beaks are small and marked along their apices, and for a short distance below, by a slight notch or slit, from the remoral of a narrow ridge which has marked the interior of the shell, as in Anatina, and supporting the cartilage-pit. The shell, in its external form, has all the features of Thracia, being slightly inequivalve and also slightly twisted when viewed in profile, and also in the character of the surface markings. The muscular impressions or pallial line cannot be distinguished through the remaining shell, and we are tberefore in doubt concerning these features. It bears considerable resemblance to Thracia gracilis M. \& H. (Pal. U. S. Geol. Surv. Territ., p. 224, Pl. 30, fig. 6), but is proportionally shorter and somewhat more contracted in height posteriorly.

Formation and locality.-In Cretaceous rocks, probably near the top of No. 4 ; near French Creek, on the Cheyenne Rirer, Dakota. 


\section{GASTEROPODA.}

Fusus Cheyennensis, $n$. $s p$.

Plate 12, fig. 9.

Shell small, spire slender and elerated, the number of rolutious unknown, but probably six or more, strongly rounded, the last one somewhat rentricose above the middle but attenuate below; aperture semiovate, being rather straightened on the inner side and slightly produced below. Volutions crossed by numerous rertical folds or plicæ, which are very slightly bent backward in their course across the volution. Surface of the shell unknown.

The specimen from which the description is drawn is an internal cast, and therefore the external characters cannot be given in detail. The species is, however, so entirely distinct from any of the forms known from this region, that there is no fear of its being confounded with any of them.

Formation and locality.-In the gray shales near the upper part of the Fort Pierre group. On the Cheyenne River, near Rapid Creek, Black Hills, Dakota.

\section{APORRHAI's MEEKI, n. $s p$.}

Plate 12, fig. 5.

Shell of moderate size, with a low, very obtusely pointed spire, which is composed of only three rentricose or rounded rolutions, exclusire of the apertural expansion, and which rapidly increase in size ; apical angle nearly eighty degrees. Volutions marked by numerous sharply elevated revolving lines, with concave interspaces both abore and below the middle. Onter lip expanded, and extended into two diverging carinated digitations of an undetermined length, which are deeply grooved on the inner face, the upper one being directed slightly backward toward the spire, and the other one slightly downward and more strongly forward in the direction of the coil of the shell; anterior beak, judging from the part remaining, moderately long and stout; posterior canal extending along the spine to the summit, where it appears to have become free and deflected; callous slight(?), coating the upper volutions orer a part of their extent.

This species differs from any previously described form of this group, in the short obtuse spire, combined with the two digitations of the outer lip, and the posterior canal which extends to the summit of the spire.

Formation and locality.-In limestone of the Fort Pierre group, at the top of the gray shales of this formation. On the Cheyenne Rirer, near Rapid Creek, Black Hills, Dakota. 
APORRhais (GONIOCheIla) CASTORENSIS, $n . s p$.

Plate 12, fig. 1.

Shell small, with a moderately elerated spire, composed of about four flattened or very slightly ventricose volutions, which are crossed by fine flexuous, vertical folds, strongly directed forward in their course across the whorl, and also marked by fine thread-like revolving lines; suture distinct; apical angle about $40^{\circ}$, but slightly variable on different individuals. Body volution proportionally large and very strongly angular, or eren carinate, along the middle, flattened or s lightly concave on the upper surface and rapidly contracted below to the short, pointed rostral beak. A second rather indistinct carination marks the surface a little below the first, but seldom or never extends to the margin of the lip. Outer lip expanded, strongly carinate on the back and projecting in the middle, to form a short, obtuse, slightly recurved digitation, and posteriorly extending along the spire to the base of the second volution abore.

This species somewhat resembles $A$. biangulata, M. \& H. (Pal. U. S. Geol. Surr. Territ., p. 322, pl. 19, fig. 6), but differs in the subdued character of the lower carination aud in the strongly uniangular form of the body rolution. Among a number of specimens none show the posterior canal extending above the point described, nor any evidence of a second digitation to the lip. The surface markings are quite superficial, but few specimens showing them, appearing quite smooth from slight exfoliation.

We are extremely arerse to describing new species of this group of shells, as, from their extreme liability to rariation with different degrees of derelopment, they are easily mistaken; and we hare feared that this might prove, on the examination of a larger and better collection of specimens, to be ouly a form of $A$. biangulata, M. \& H., abore referred to; but the single strong carination, and the fact that it comes from a lower geological horizon and distant locality, have induced us to separate it under a new name.

Formation and locality.-In a ferruginous sandy limestone, on the East Fork of Beaver Creek, Black Hills. Associated with fossils of the Fort Benton group.

\section{Gexus AKERA, O. F. Muller.}

AKERA GLANS-ORYZA, $n . s p$.

Plate 12, fig. 25.

Shell minute, not exceeding one-fifth of an inch in length, and the diameter being about $t$ wice and a half less than the length; cyliudrical in form, with a very low, truncated spire, which consists of about three or three and a half volutions, the outer margins of which are bordered 
by au elerated knife-edge carina, giring a deeply channeled convolute character to the spire, the center scarcely rising above the level of the outer carination. Body of the outer volution very slightly rounded near the margin of the flattened spire, and distinctly so to the base below. Aperture as long as the shell, narrow above and gradualiy widening and rounded at the base. Columella curved and apparently reflected upon the preceding rolution. Axis imperforate.

Surface of the shell marked by very fine, revolving, impressed lines, strongest near the top of the rolution and on the lower third; also by finer transverse strix of growth, parallel to the margin of the aperture, and indicating by their direction that the central portion of the outer lip is a little in adrance of the top and base.

Formation and locality.-In limestone, near the top of the Fort Pierré gronp. On the Chesenne River, near French Creek, Black Hills, Dakota.

\section{CEPHALOPODA.}

\section{Gexus HELICOCERAS, D'Orb.}

\section{HeLICOCER 4 S STLVENSONI, $n . s p$.}

Plate 14, figs. 4-7.

Shell large and robust, with an elevated, moderately tapering spire, which is composed of strong, cylindrical, disconnected, dextrally coiled rolutions, sharply enrolled-and learing an umbilical opening equal to, or a little greater than, one-half the diameter of the rolution encircling it. The rolutions are at first widely disconnected and rapidly descending, but become more closely coiled below, and in the lower part of the example figured are but slightly disconnected.

Surface of the shell marked by strong, rounded, annulating costa, passing entirely around the shell, and separated by wider concave interspaces. On the upper surface of the volution the costa are strongly directed backward, but are recurred, aud on the outer face are directed gently forward below and within the umbilicus. The costa are further ornamented bs two irregular rows of strong, obliquely-rounded, tuberculose nodes, the upper range being situated along the middle of the rolution, and the other half-way between it and the center of the basal surface. The nodes of the two ranges, although usually placed on the same costa, are not constantly so, bui frequently alternate, and in very many cases two of the costa unite at the lower node, continuing only as one on the lower side of the volution.

Septa rather distantly arranged, learing considerable space between them, the convolutions of a single septum occupying a space on the periphery of the shell, equal to from two-thirds to three-fourths of the diameter of the volution, at the point examined. Siphonal lobe longer than wide, and deeply dirided at the extremity into two principal branches, each of which are again deeply divided, and the dirisions 
furnished with numerous serrated digitations. First lateral lobe very large and unequally divided into two principal branches, the outer one of which is the largest, and each is again divided and furnished with numerous compound digitations. The second lateral lobe is much smaller than the first, and similarly divided, but the divisions are smaller and'less complicated. (The inner half of this lobe has not been distinctly traced.) First lateral sinus rather large and deeply cleft in the middle by an auxiliary lobe, the lower end of which is divided into several digitations. Second lateral sinus shorter and comparatively more spreading than the first also, and deeply divided in the middle by a simple auxiliary lobe having four spurs on each side. Other lobes and sinuses not observed. Siphuncle rather small, marginal, and passing along the middle of the volution.

This species would appear, without critical examination, to be somewhat closely related to Heteroceras? angulatum, M. \& H. (Pal. U. S. GeolSurv. Territ., p. 484, pl. 21, fig. 3), more especially as their species is stated to be "(dextral?)"; and their figures, being placed base upward, which may be seen by the position of the nodes, are liable to mislead, but if critically examined will be found, from the direction of the costa, to belong to a sinistral shell, as they incline in an opposite direction to those of a dextral shell. Mr. Meek states loc. cite that the fragment figured is supposed to be from the deflected part of the shell, and for this reason is placed provisionally, with doubt, under the genus Heteroceras. It is, perhaps, impossible for one to feel positive that a shell of this group has not been, or would not be, deflected at some period of growth, unless a perfect adult individual is obtained. Our shell figured shows no evidence whatever of any tendency to become deflected; still it is known to be imperfect, as it is septate to within an inch of the outer extremity, and we cannot therefore feel positive of its true generic relations. The upper part of the spire has, however, been very loosely coiled, or widely disconnected, becoming more compact with increased growth; in this respect being the reverse of shells belonging to the genus Heteroceras. Owing to this feature, and the absence of any evidence of the generically-required deflection in the adult stages, we have considered it most natural to refer it to Felicoceras.

Formation and locality.-In limestone of the Fort Pierré group, on the west side of Beaver Creek, southwest Black Hills.

\section{Genus HeTEROCERAS, D'Orb.}

Heteroceras NewTONI, $n . s p$.

Plate 15, figs. 1-4.

Shell dextral, of moderate size, composed of from two and a half to three, loosely coiled, disconnected, and rather rapidly increasing volutions forming the rather low but somewhat rapidly spreading 
spire, below which point the shell is deflected to an unknown extent. Transverse section of the shell circular, or nearly so. Umbilicus very wide in the upper part of the spire, but scarcely increasing in diameter with the increased growth of the shell above the deflected portion, the increased diameter of the tube about equaling the increased diameter of the whorl.

Surface of the shell ornamented by lor, subangular, transverse ridges or costa, which pass entirely around the shell and are separated by wider concave interspaces; also by two longitudinal rows of obliquely rounded nodes, the upper one of which is placed at, or just below, the periphery, and the other at about one-eighth of the circumference of the tube below the first, and on the line of the same ridge with it. Transverse costa arranged in sets of three; two of each set coalescing to form the oblique nodes, the third one passing around the tube, without interruption, midway between the two adjacent pairs of nodes. The direction of the costa is strongly backward on the upper inner surface of the rolution, then recurving and passing obliquely forward in crossing the outer face of the shell from abore to the base, and also within the umbilicus. Siphuncle small, marginal, situated as far above the upper line of nodes as the distance between the two lines.

Septa approximate, the extremities of the lobes of one slightly inter. fering with those of the saddles of the next adjacent, but not interlocking; the space occupied by the convolutions of the lobes and sinuses of a septum is equal to three-fifths of the diameter of the tube at the position of the septum measured; the ramifications of the lobes are sharply angular and pointed. The siphonal lobe is longer than wide, deeply divided at the extremity into two rather long, compound digitate. processes, and a short median bifid process. First lateral lobe very deeply and unequally divided and the branches widely spreading, and deeply serrate-digitate. Second lateral lobe very much smaller than the first and lesis spreading. Antisiphonal lnbe single, longer than wide, deeply digitate on the side and dirided into four small, nnequal digitations at the extremity. Sinuses large, spreading, and deeply cleft by auxiliary or secondary lobes.

The type specimen of the species is imperfect, but preserves one and one-third volutions; the rolutions are entirely disconnected and increase rapidly in size, while the umbilicus retains the same diameter, the upper volutions appearing to have been not more closely coiled than those preserved. The outer extremity of the specimen retains a part of the deflected portion which is bent downward as well as outward, and is septate nearly to the end. The species appears to be related to $H$. ? Nebracensis, M. \& H., Pal. U. S. Geol. Surv. Territ., p. 480, pl. 22, fig. 1, $a, b, c$, but differs, however, in the more rapidly increasing volutions; in the disconnected whorls; simple costa (i. e., not bifurcating); in the position of the siphuncle, and in the details of the lobes and sinuses.

Formation and locality.-In limestones of the Fort Pierre group, on the west side of Beaver Creek, southwest Black Hills. 


\section{Genus ANCYLOCERAS, D'Orb.}

\section{ANCYloceras JENNEyi, n. $s p$.}

Plate 16, figs. 6-8.

Shell of moderate size, composed of two or more(?) rapidly-increasing rolutions, enrolled on the same plane, and entirely disconnected; the inner ones apparently leaving a broad, open umbilical space. Shell rather rapidly increasing in size with increased age. Volutions slightly flattened, on the back rerticall. compressed and transversely oral in section; the vertical diameter being only about two-thirds as great as the dorso-ventral in the larger part of the shell, the greatest height being nearest to the ventral margin.

Surface of the shell marked by strong, distant, transverse, encircling ridges, which are directed slightly forward in passing from the dorsal to the ventral margin, and in crossing the latter they become nearly obsolete. Occasional intercalated ridges occur at irregular distances on the dorsal side. Intercostal spaces concave. The shell is further ornamented by two lines of obtusely rounded nodes, which are situated on the ribs at the angles of the flattened dorsum.

Septa somewhat complicated and closely arranged, sothat the inner lobes interfere with the extremities of the sinuses of the one in advance but on the dorsal portion the are more distant. Siphonal lobe longer than wide, deeply divided at the extremity and terminating in two large, strongly serrated digitations, having one or two lateral spurs on their outer side. First lateral lobe large, deeply bipartite, each branch terminating in two or three unequal digitations, and with sereral smaller spurs on the sides above. Second lateral lobe much smaller than the first, deeply bipartite, with numerous strong spurs irregularly arranged along the margins. Antisiphonal lobe long, narrow and simple, but with long lateral serrated spurs and a slightly tripartite extremity. First and second sinuosities rather large, deeply divided by large auxiliary lobes into two principal branches, which are again deeply divided. Third sinus smaller than the others and dirided into two principal branches. The margins of all lobes and sinusés deeply serrated.

The species is described from an imperfect individual, and a second smaller fragment of a larger specimen. They consist only of the conrolute parts, and show no evidence of the deflection of the tube. It is possible they are not rightly referred to the genus Ancyloceras, but are more nearly related to the genus Anisoceras of Pictet, which differs from the former genus in being irregularly helicoid. The example figured would seem to hare been somewhat irregularly coiled, but this may possibly be the effects of distortion, as the smaller coils of the shell are considerably displaced. It differs from Ancyloceras also, as defined by Mr. F. B. Meek (Pal. U. S. Geol. Surr. Territ., p. 409), in haring 
the termiuations of the lobes bipratite instead of tripartite; but this character does not appear to hold good among many of those referred to the genus, and as we bave not seen the septa of the type species we are uncertain if it is an original feature of the genus or only an errone. ously added one.

Formation and locality.-In limestone referred to the Fort Pierre group of the Upper Missouri Cretaceous, on the East Fork of Beaver Creek, three miles rest of Camp Jeuner, Black Hills.

\section{AnCiloceras tricostatus, $n . s p$.}

Plate 15 , figs. 7 and 8.

A single fragment of a sinistra, helicoid shell, the volutions of which have been entirely separate and coiled upon the same plane, with a rapidly increasing curvature, appears to possess features entirely distinct from those of any described species. The form of the volution has been quadrangularly urate in section, vertically compressed, with the greatest vertical thickness at about the inner third of the width, and slightly flattened on the dorsum. The shell is marked by a line of strong, angular nodes on each dorsal angle, aud by closely arranged, subangular, encircling ridges or costa, which are directed slightly forward in crossing from the rentral to the dorsal margin on the upper side of the rolution, and much more strongly so in crossing from the upper to the lower side of the dorsal flattening, and are recurved below and on the umbilical surface. The costa are arranged in sets of three, the two adjacent ones of which unite in the nodes on the upper and lower dorsal angles, while the third ridge of each set encircles the shell between the nodes of two adjacent sets. Intercostal spaces concave.

Septa rery complicated and distant; the space between two adjacent ones equal to about one-third of the space occupied by the convolutions of a single septum, at the point indicated. The dorsal lobe is almost twice as long as wide, deeply divided at the lower extremity by a broad tridentate sinus, each division being again divided into two widely divergent, dentate branches. There are also two lateral dentate spurs abore on each side of the lobe. First lateral lobe large, but slender; divided into two principal widely divergent branches, each of which is again dirided and furnished with sereral strong dentate spurs on the margins; two other spurs of similar character exist on each side of the lobe, one just below the bifurcation, and the other some distance above. Second lateral lobe smaller than the first, deeply divided, with the branches less divergent, but again divided, and the inner branches trifurcate, the outer branches short and strongly dentate. Antisiphonal lobe small and simple, marked by one small spur on each side abore, and two larger curved and dentate ones below; the central termination being minutely tridentate at its extremity. First lateral sinus large, rery deeply dicided into two principal branches, each of which is 
deeply divided above and strongly lobed on the sides. Second sinus smaller, less deeply and unequally divided, the outer half smallest and deeply lobed, the other less deeply so. Antisiphonal sinus very large (considering the parts separated by the antisiphonal lobe as one sinus), the antisiphonal lobe dividing it nearly to the base, and the divisions again very deeply divided and deeply lobed on the sides. Siphuncle small, situated between the lines of nodes and marginal.

This species differs from Ancyloceras Jenneyi in being sinistrally coiled, and in the character of the ridges of the surface and angular nodes. We know of no other species described with which it is enough related to require a comparison.

Formation and locality.-In limestone at the top of the Fort Pierre group, on the Cheyenne, near French Creek, Black Hills, Dakota.

\section{Ptychochras meekanum, $n . s p$.}

Plate 16, figs. 1 and 2.

Shell of small size, subcylindrical or vertically compressed, giving a somewhat oblate-transverse section, very gradually increasing in diam. eter with the increased.length; smaller limb slender, gently curved or bent in the middle of its length, so as to give the earlier and middle portions of the shell an angle of about $135^{\circ}$ to each other. Larger limb or outer chamber closely appressed and slightly embracing the smaller, and extending to near the middle of the curvature.

Surface of the entire shell marked by strong, simple, sharply angular, oblique, encircling ridges, with wider, deeply concave interspaces, very regularly increasing in distance from the apex outward, and on the dorsal region by two longitudinal rows of spines or spiniform tubercles, situated at about or nearly one-sixth of the circumference of the tube from each other, and on the crests of the ridges. The encircling ridges are directed obliquely forward in passing from the ventral to the dorsal surface in the smaller limb, but have the opposite direction on the larger; space between the lines of nodes very gently concave.

Septa approximate, but more distant than the surface-ridges of the shell, deeply lobed, and the lobes and sinuses somewhat complicated. The dorsal or siphonal lobes are nearly as wide as long, broadly forked at the extremity, and the outer side of the forks marked by several short rounded digitations. First lateral lobe divided into two diverging branches, with lobed margins. Second lateral lobe narrower and more slender than the first, and more deeply forked; the division being marked by short rounded digitations. Ventral or antisiphonal lobe small, but deeply forked, and the margins sinuous. Sinuses nearly equal in size, each of them deeply divided in the middle by an auxiliary lobe; slightly bifid in the first and second but simple in the third; division of the sinuses marked by short rounded digitations. Siphon of moderate size, marginal, and placed between the lines of nodes. 
Before entering upon a critical study of the specimens before us, we had supposed them to be identical with Ptychoceras Mortoni M. \& H., and hesitated to consider them as distinct; but there are so many points of difference, and the variations are so great, that it appears impossible to aroid this conclusion, and equally difficult to unite the two forms here mentioned. More especially is this the case if any reliance is to be placed on the structure and location of the septa. We are quite well aware that this latter feature is one liable to great variation, dependant upon the growth of the individual; but the lobations in the septa at the smaller extremity of the specimen figured is much more complicated than that shown by Mr. Meek, to exist in the type specimen of $P$. Mortoni. Beside the difference in the septa, the form of the tube varies in being wider than high, the reverse of that species, and the antisiphonal surface of the tube is always flattened, and the costa alwass simple.

Formation and locality.-In limestone of the Fort Pierré group, ou Bearer Creek, Black Hills.

\section{Ptychoceras CRassum, n. $s p$.}

Plate 16, figs. 3-5.

Entire form of shell unknown. The portion preserred is rather robust in habit and the shell much thickened, except on the rentral surfaces. Transrerse section subcylindrical or slightly compressed in a dorso-ventral direction, the larger limb being concave on the ventral side and slightly embracing the smaller part. Tube regularly increasing in diameter with increased growth. Shell oruamented by strong, sharply angular, encircling ridges, which are directed forward in passing from the ventral to the dorsal sides of the smaller limb, but have the opposite direction on the larger part; also by two longitudinal lines of pointed nodes or spines on the dorsum, which are separated by a moderately wide, slightly concave space.

Septa distant, one septum nearly equaling two of the transverse ridges, except near the bending of the tube where there are two of, the septa placed nearer to each other, bejond which the shell is not septate. Lobes and sinuses of the septa somewhat complicated; the siphonal lobe longer than wide, and broadly forked at the extremity. First lateral lobe large, divided into two principal branches, the outer one being again deeply divided, and the margins of the branches serratodigitate. Second lateral lobe smaller than the first, divided into three short serrate digitations. Antisiphonal lobe small and simple, marked only by two short digitations on each side. First and second sinuses much larger and broader than the lobes, deeply divided in the middle by a small serrated auxiliary lobe, and the dirisions each again dirided and serrate. Antisiphonal sinus a little smaller than the others, but more deeply dirided by the antisiphonal lobe, and the branches again 
deeply divided. All the margins of the lobes and sinuses are characterized by small, rounded serrations. Siphuncle of moderate size, marginal and situated between the lines of nodes.

The distinction between this and the preceding species consists in its large size, more robust habit, and thicker shell, and in the more distant and much more complicated septa. It is still further remover by these characters from $P$. Mortoni M. \& H., as well as by the simple ridges.

Formation and locality.-In limestone of the Fort Pierré group, on Old Woman's Fork, Black Hills.

\section{LIST OF FOSSILS DESCRIBED IN THE REPORT OF THE PAILONTOLOGY OF THE BLACK HIILS.}

\section{POTSDAM GROUP.}

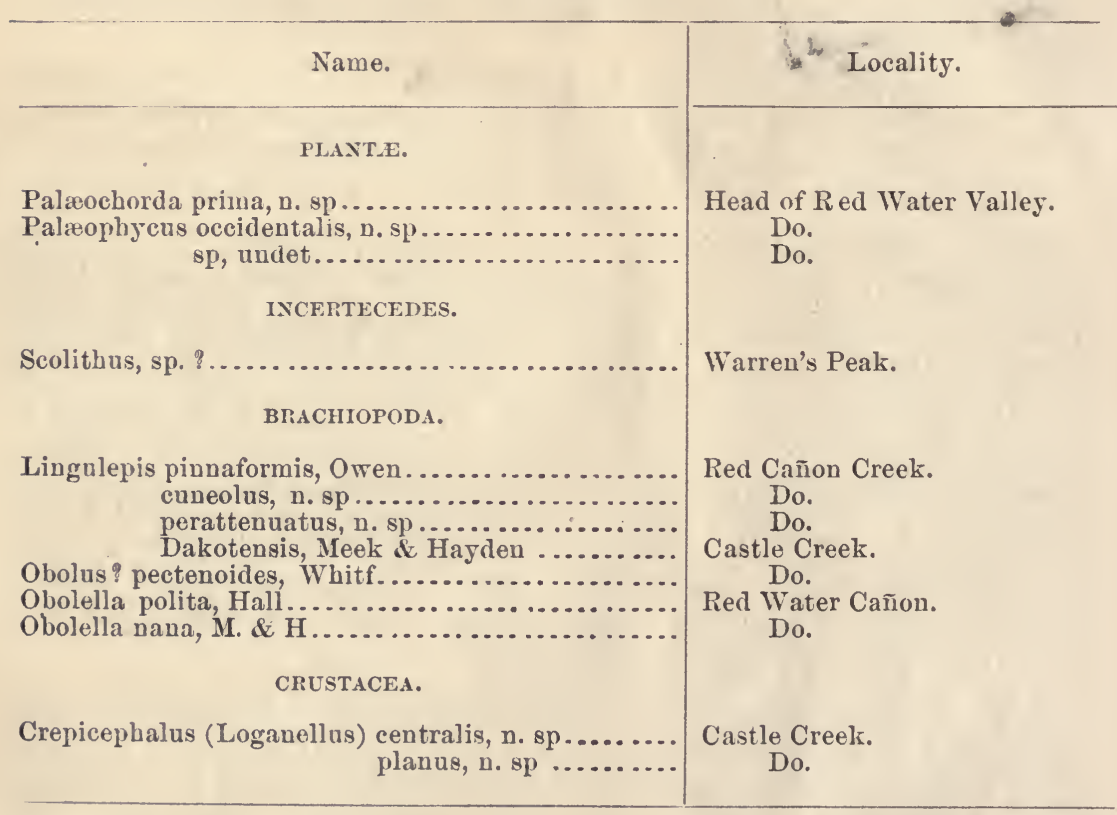

\section{JURASSIC.}

\section{RADIATA.}

Asterias? dnbinm, n. sp. .

Pentacrinus asteriscus, M. \& H.

\section{BRACHIOPODA.}

Lingula brevirostris, M. \& $\mathrm{H}$.

Rhyuchonella myrina, H. \&. W
Spear's Fork of Red Water Creek. Big Horn Mountains.

Spear's Fork of Red Water Creek. Red Cañon Creek. 
List of Fossils, ffe.--Continued.

JURASSIC.

Name.

\section{LAMELLIBRANCHLATA.}

Ostrea strigilecula, White

Gryphrea calceola var. Nebracensis, M. \& H. Pecten Newberryi, n. sp...................... Camptonectes bellistriata, Meek ................ extennatus, M. \& H............. Pseudomonotis (Eumicrotis) curta, Hall.......... orbiculata, n. sp.....

Avicula (Oxytoma) mucronata, M. \& H......... Gervillia recta, Meek in MS.................. Grammatodon inornatus, M. \& H...............

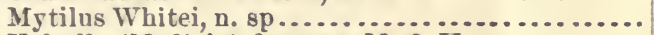
Volsella (Modiola) formosa, M. \& $\mathrm{H}$. pertennis, M. \& $\mathrm{H}$

Astarte fragilis, M. \& H.....................

Trapezium bellefourchensis, n. sp.............. subequalis, $\mathrm{n} . \mathrm{sp} . . . \ldots \ldots \ldots . . . . . . .$.

Pleuromsa Newtoni, n. sp ......................

Tancredia (?) inornata, M. \& H. corbuliformis, n. sp.................. bulbosa, n. sp..................... postica, .. sp ...................... Warrenana, if. \& H ..............

Dosinia Jurassica, n. sp ..................... Psammobia (?) prematura, n. $\mathrm{sp} . . . . \ldots \ldots . . . .$.

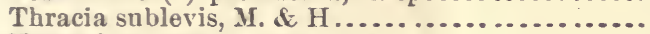

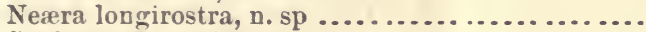
Saxicava Jurassica, n. sp ......................

\section{CEPHALOPODA.}

Ammonites cordiformis, M. \& H. var. distans.

Belemnites densus, If \& $H$.
Locality.

Belle Fourche, Sun-Dance Hills, and near Bearer Creek.

Big Horn Mountains.

Belle Fourche.

East of Belle Fourche.

Two miles south of Belle Fourche, Red Water Valley.

Two miles south of Belle Fourche. Sun-Dance Hills.

Sun-Dance Hills.

Big Horn Mountains.

(September 20.)

Red Water Valley.

East of Belle Fourche.

Red Cañon Creek.

Two miles south of Belle Fourcbe.

East of Belle Fourche.

Do.

Do.

Do.

Red Water Valley.

East of Belle Fourche, \&c. Do.

Red Water Valley.

Do.

Do.

Red Water Valley.

Two miles sonth of Belle Fourche. East of Belle Fourche.

\section{CRETACEOUS.}

\begin{tabular}{|c|c|c|}
\hline Sjstematic name. & Division. & Locality. \\
\hline \multicolumn{3}{|l|}{ LANELLIBRANCHIATA. } \\
\hline Cyncyclonema rigida, $\mathbf{\text { I. }}$ \& $\mathrm{H}$....... & No. 4 . & Forks of the Cheyenne River. \\
\hline Pteria linguifornis, Evans \& Shum... & No. 4. & $\begin{array}{l}\text { Cheyenne River, near French } \\
\text { Creek, \&c. }\end{array}$ \\
\hline $\begin{array}{l}\text { (Oxstoma) Nebrascana, E. \& S. } \\
\text { (Psendopteria) tibrosa, M. \& H. }\end{array}$ & $\begin{array}{l}\text { No. } 4 \ldots \ldots \ldots \\
\text { No. } 4 \ldots \ldots .\end{array}$ & $\begin{array}{l}\text { Sage Creek. } \\
\text { Cheyenne River, near Rapid }\end{array}$ \\
\hline sublævis, n. sp.. & No. $4 \ldots . .$. . & $\begin{array}{l}\text { Creek. } \\
\text { Old Woman's Fork. }\end{array}$ \\
\hline Inocerauns problematicus, Schlott... & Nos. 2 and 3 . & East Fork of Bewver Creek. \\
\hline $\begin{array}{l}\text { fragilis, H. \& M.......... } \\
\text { altus, Meek .............. }\end{array}$ & $\begin{array}{l}\text { Nos. } 2 \text { and } 3 . \\
\text { No. } 2 \ldots . . .\end{array}$ & $\begin{array}{l}\text { Beaver Creek. } \\
\text { Belle Fourche, } 10 \text { miles west of } \\
\text { Crow Creek. }\end{array}$ \\
\hline perplexus, n. sp. & No. $2 \ldots . .$. & $\begin{array}{l}\text { Belle Fourche, } 10 \text { miles west of } \\
\text { Crow Creek. }\end{array}$ \\
\hline $\begin{array}{l}\text { sublævis, H. \& M... } \\
\text { Sagensis, Owen ..... }\end{array}$ & $\begin{array}{l}\text { No. } 4 \ldots \\
\text { No. } 4 \ldots\end{array}$ & Forks of the Cheyenne River. \\
\hline
\end{tabular}


List of Fossils, \&c.-Continued.

CRETACEOUS.

$\frac{\text { Systematic name. }}{\text { LaMellibraxchiata-Continued. }}$

Inoceramus Simpsoni, Meek.......... Vanuxemi, M. \& H....... var..........

Barabini, Morton tenuilineatus, M. \& H ...

Endocostea typica, 11. sp............ sulcata, Roumer ......... Idonearca Shumardi, M. \& H.........

Nucula planimarginata, M. \& H...... Nuculana bisulcata, M.\& H......... subeqnilatera, $n$. sp........

Yoldia Evansi, M. \&. H.

Lucina occidentalis, Morton.......... ventricosa, H. \& M............ (Diplodonta)subundata, H.\&M. Crassatella subquadrata, n. sp ....... Astarte Evansi, H. \& M.............

Veniella humilis, M. \& H............

Sphæriola transversa, n. $\mathrm{sp}$..........

Dosinia Missouriana, Morton

Thetis circularis, M. \& H............

Leiopistha (Cymella) Meeki, n. sp ....

Thracia subgracilis, n. sp ...........

Neæra Moreauensis, M. \& H?

\section{GASTEROPODA.}

Fasciolaria (Cryptorhstis) fusiformis, H. \& M.

Fasciolaria (Cryptorhytis) contorta, M. (Piestocheilus) Culbertsoni, M. \& H.

Fusus Shumardi, H. \& M............

Chejennensis, n. sp.............

A porrhais Newberryi, Meek ...........

Meeki, n. sp..............

(Goniocheilus) Castorensis, n. sp.

Anchura? sublævis, M. \& H

(Drepanocheilus) Nebracen-

sis, E. \& S................

Lunatia concinna, H. $\& . W . . . . . .$.

Vanikora ambigua, M. \& H
Division.

Locality.
No. 4 .......

No. 4 .......

No. 4 .......

No. 4 .......

No. 4 .......

Nos. 4 and 5.

Nos. 4 and 5.

No. 5 .......

No. 4 ....... Nos. 4 and 5 .

No. 4 .......

No. 4 or $5 . .$.

Nos. 4 and 5 .

No. 4.

No. 4 .......

No. 4 ?

No. 4 ......

No. $5 . . . .$.

No. 5 ........

No. 4 .

No. 4 .......

No. 5......

No. 4 .......

No, 4 .......

No. 4 ....... No. 4 or 5 ... No. 4 or $5 . .$.

No. 2.......

No. 4 .......

No. 5 .......

No. $4 . . . . .$.

No. 4 or 5 ...

No. 4 ....... No. 4 or $5 .$.

No. 4 ......

No. 4
Old Woman's Fork. J).

Belle Fonrche, 10 miles west of Crow Creek:

Cheyenne River, near Box Elder Creek.

Old Woman's Fork.

Loose on Beaver Creek.

Cheyenne River, near Old Woman's Fork.

Cheyeune River, (May 31.)

Cheyenne River, near Box Elder Creek.

Cheyenue River, near French Creek.

old Woman's Fork, \&c.

Cheyenne River, near Rapid Creek.

Cheyenne River, near Rapid Creek.

Cheyenne River, near Rapid Creek.

Cheyenne River.

Cheyenne River, near Rapid Creek.

Cheyenne River, near Old Woman's Fork.

Cheyenne River, near Old Woman's Fork.

Cheyenne River.

Cheyenne River, near Rapid Creek.

Dead Man's Rapids, Upper Missouri.

Cheyenne River, near Rapid Creek.

F'orks of the Cheyenne River.

Cheyenne River, near Rapid Creek.

Old Woman's Fork.

Near French Creek.

East Fork of Beaver Creek.

Cheyenne River, near Rapid Creek.

Rio de la Plata.

Cheyenne River, near Rapid Creek.

East Fork of Beaver Creek.

Near Box Elder Creek.

East Fork of Beaver Creek.

Cheyenne River, near Rapid Creek.

Cheyenue River. 
List of Fossils, \&e.-Continued.

CRETACEOUS.

\begin{tabular}{|c|c|c|}
\hline Systematic name. & Division. & Locality. \\
\hline GaSteropoda-Continued. & & \\
\hline Amauropsis paludinæformis, H. \& M.. & No. 4. & Cheyenne River, near Box Elder \\
\hline Margarita Nebracensis, M. \& H ...... & No. 4. & 150 miles above mouth of Yellow- \\
\hline Anisomyon alveolus, M. \& H. & No. 4 & $\begin{array}{l}\text { stone. } \\
\text { old Woman's Fork. }\end{array}$ \\
\hline subovatus, M. \& H....... & No. 4 . & Do. \\
\hline patelliformis, M. \& H .... & No. 4. & Do. \\
\hline $\begin{array}{l}\text { borealis, Morton........... } \\
\text { Akera glans-oryza, n. sp .............. }\end{array}$ & $\begin{array}{l}\text { No. } 4 \ldots \\
\text { No. } 4 \ldots\end{array}$ & $\begin{array}{l}\text { Cheyenne River. } \\
\text { Cheyenne River, near French }\end{array}$ \\
\hline Haminea subcrlindrica, M. & & $\begin{array}{l}\text { Creek. } \\
\text { old Woman's Fork. }\end{array}$ \\
\hline Dentalium gracile, H. \& M............ & No. & $\begin{array}{l}\text { Cheyenne River, near Rapid } \\
\text { Creek. }\end{array}$ \\
\hline CEPHAT & & \\
\hline Nautilus Dekayi var. Montanensis, M. & No. 4. & Cheyenne River, near Rapid \\
\hline lus Wyomingensis, Meek.... & No. & \\
\hline Scaphites nodosus, Ow & & $\begin{array}{l}\text { Cheyenne River, near Rapid } \\
\text { Creek. }\end{array}$ \\
\hline var. brevis, Meek.. & No. 4 & $\begin{array}{l}\text { Cheyenne River, near Rapid } \\
\text { Creek. }\end{array}$ \\
\hline $\begin{array}{l}\text { quadrang u- } \\
\text { laris, Meek. }\end{array}$ & No. 4. & $\begin{array}{l}\text { Cheyenne River, near Rapid } \\
\text { Creek. }\end{array}$ \\
\hline $\begin{array}{l}\text { plenus, M \& H. } \\
\text { Warreni, M. \& H.......... }\end{array}$ & $\begin{array}{l}\text { No. } 4 \ldots \\
\text { No. } 2 \ldots\end{array}$ & East Fork of Beaver Creek. \\
\hline Wyomingensis, M. & No. $2 .$. & Do. \\
\hline Helicoceras Stevensoni, n. sp......... & No. $4 \ldots \ldots$..... & West of Beaver Creek. \\
\hline Heteroceras Newtoni, n. sp $\ldots \ldots \ldots \ldots$ & $\begin{array}{l}\text { No. } 4 \ldots \ldots \\
\text { No. } 4 \text { or } 5 \ldots\end{array}$ & $\begin{array}{l}\text { Do. } \\
\text { East Fork of Beaver Creek. }\end{array}$ \\
\hline Ancycloceras Jenneyi, n. sp........ & No. $4 \ldots . . .$. & Do. \\
\hline tricestat, & No. $4 \ldots$ & $\begin{array}{l}\text { Cheyenne River, near French } \\
\text { Creek. }\end{array}$ \\
\hline $\begin{array}{r}\text { Ptychoceras Meekanum, n. sp .......... } \\
\text { crassum, n. sp........... }\end{array}$ & $\begin{array}{l}\text { No. } 4 \ldots \ldots \\
\text { No. } 4 \ldots \ldots\end{array}$ & $\begin{array}{l}\text { Beaver Creek. } \\
\text { Old Woman's Fork. }\end{array}$ \\
\hline
\end{tabular}








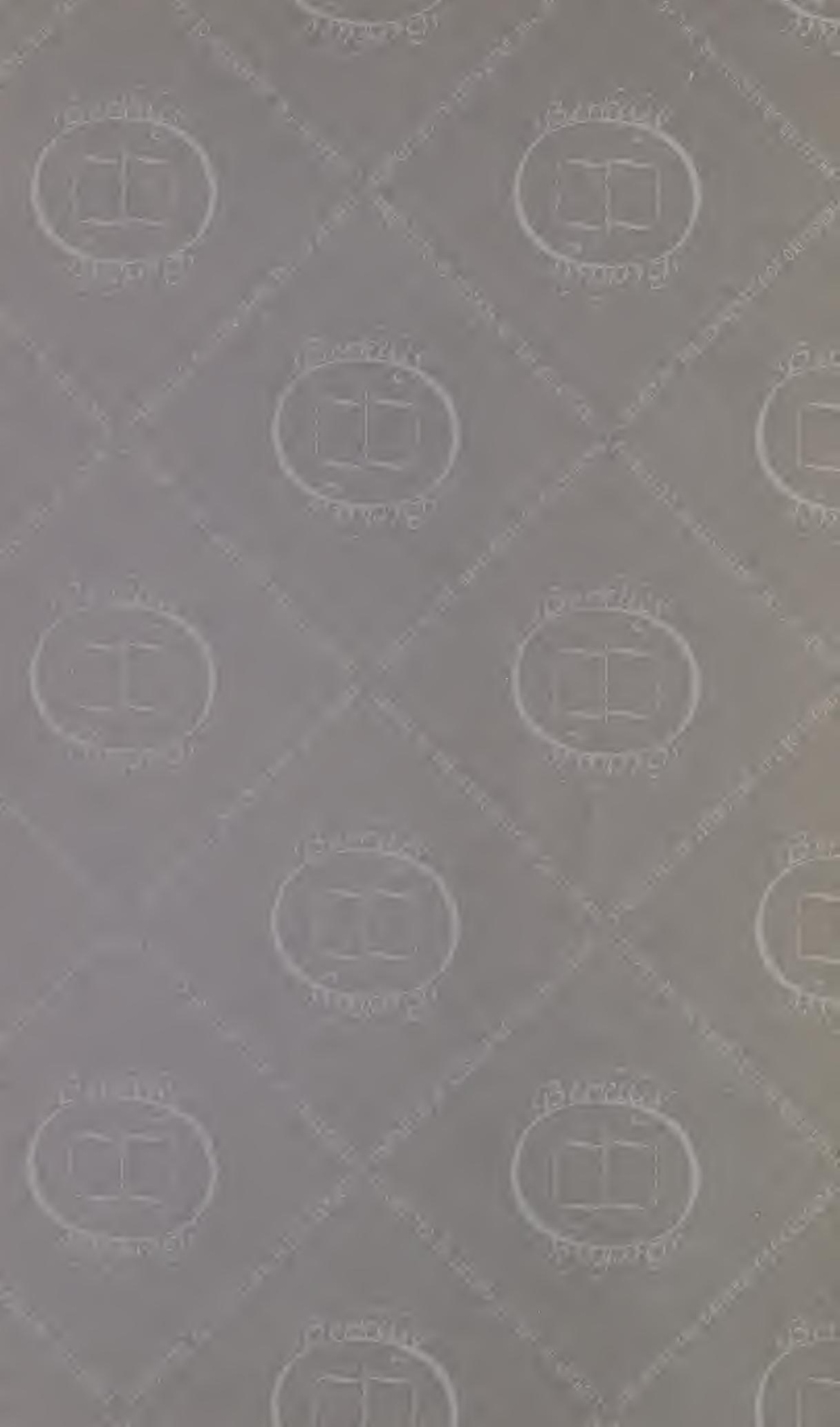



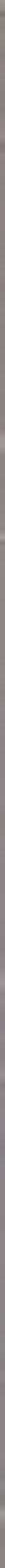

$-8$
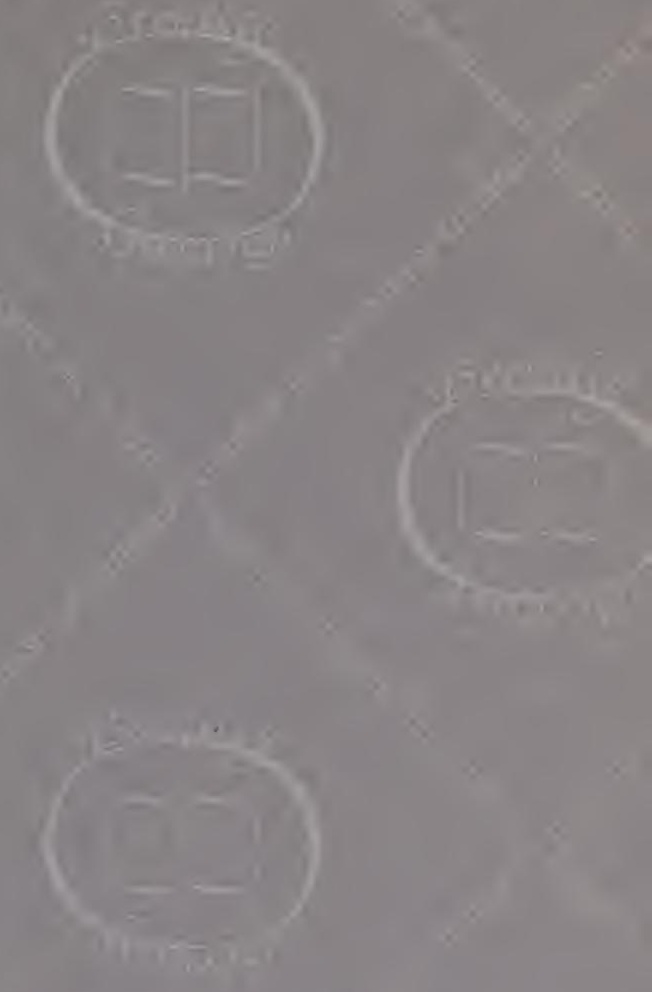
